\title{
The promoter of the mouse tissue transglutaminase gene directs tissue-specific, retinoid-regulated and apoptosis- linked expression
}

\author{
László Nagy, ${ }^{1,3,5}$ Vilmos A. Thomázy, ${ }^{1,3}$ Margaret M. Saydak, ${ }^{1}$ \\ Joseph P. Stein ${ }^{2}$ and Peter J.A. Davies ${ }^{1,4}$ \\ 1 Department of Pharmacology, University of Texas - Houston Medical School, \\ Houston, Texas 77225 , USA \\ 2 Department of Pharmacology, S.U.N.Y. Health Science Center at Syracuse, \\ Syracuse, New York, 13210-2339, USA \\ 3 Joint first authors \\ ${ }^{4}$ corresponding author: tel: 713-500-7480; fax: 713-500-7455; \\ e-mail: pdavies@farmr1.med.uth.tmc.edu \\ ${ }^{5}$ Present address: The Salk Institute for Biological Studies, Gene Expression \\ Laboratory, La Jolla, CA 92037
}

Received 26.5.97; revised 9.6.97; accepted 12.6.97

Edited by G. Melino

\begin{abstract}
Tissue transglutaminase is a multifunctional enzyme that accumulates to high levels in cells undergoing apoptosis. Retinoids act as an acute and direct regulator of tissue transglutaminase gene transcription. The studies reported here were carried out to elucidate the molecular mechanisms involved in the regulation of tissue transglutaminase expression. We have isolated and characterized the mouse tissue transglutaminase gene promoter and $3.8 \mathrm{~kb}$ of $5^{\prime}$ flanking DNA. A large fragment of the promoter that includes both the core promoter and $3.8 \mathrm{~kb}$ of 5 'flanking DNA shows retinoid-dependent transcriptional activity when stably transfected into HeLa cells. In these stably transfected HeLa cells both the endogenous tissue transglutaminase gene and transfected mouse tissue transglutaminase promoter are activated by all-trans retinoic acid and by retinoic acid receptor (RAR)-specific and retinoid X receptor (RXR)-specific retinoids. In embryos made transgenic with a transglutaminase promoter- $\beta$-galactosidase reporter gene, the transgene shows specific patterns of expression during limb development. The transglutaminase transgene is expressed in cartilage, the cells of the apical ectodermal ridge, and in regions of apoptotic cell death of the interdigital mesenchyme. It appears that cis-acting elements responsible for the complex retinoid regulation, tissue- and apoptosis-specific expression are embedded within the proximal $3.8 \mathrm{~kb}$ of DNA flanking the 5 -end of the mouse tissue transglutaminase gene.
\end{abstract}

Keywords: tissue transglutaminase; retinoids; gene; promoter; transgene; apoptosis
Abbreviations: ATRA, all-trans retinoic acid; 9-cis RA, 9-cis retinoic acid; TTNPB, (E)-4-[2-(5,6,7,8-tetrahydro-5,5,8,8,tetramethyl-2-napthalenyl)-1-propenyl]benzoic acid; Am80, 4(5,6,7,8-tetrahydro-5,5,8,8-tetramethyl-2-naphthalenylcarbamoyl)benzoic acid; LGD1069, (4-[1-(3,5,5,8,8-pentamethyl5,6,7,8-tetrahydro-2-napthyl)ethenyl]benzoic acid; RAR, retinoic acid receptor; $R X R$, retinoid X receptor; RARE, retinoic acid receptor response element; $\beta$ RARE, RARE in the promoter of the RAR $\beta$ gene; RXRE, retinoid $X$ receptor response element; ONPG, o-nitrophenyl- $\beta$-D-galactopyranoside; DMEM, Dulbecco's modified Eagle's medium; CAT, chloramphenicol acetyltransferase; EDTA, ethylenediaminetetraacetic acid; DTT dithiothreitol.

\section{Introduction}

Transglutaminases are a family of enzymes that catalyze the covalent cross-linking of proteins by promoting the formation of $\varepsilon(-\gamma$-glutaminyl)-lysyl isopeptide bonds between protein bound glutamine and lysine residues (Folk, 1980; Greenberg et al, 1991). Transglutaminases also catalyze the covalent conjugation of polyamines to proteins (Davies et al, 1989). In spite of the apparent similarity in the biochemical reactions catalyzed by members of the transglutaminase family each enzyme participates in distinct physiological processes. Some transglutaminases such as plasma Factor XIIla or seminal plasma transglutaminase are extracellular enzymes involved in the cross-linking of protein aggregates during biological clotting reactions (Aeschlimann and Paulsson, 1994; Greenberg et al, 1991). Other transglutaminases, such as keratinocyte transglutaminase (transglutaminase type I) or epidermal transglutaminase, are tissue-specific intracellular enzymes involved in the cross-linking of structural proteins during squamous differentiation (Aeschlimann and Paulsson, 1994; Greenberg et al, 1991). Tissue transglutaminase is an unusual enzyme in that it seems to contribute to both intracellular and extracellular physiological processes (Aeschlimann and Paulsson, 1994; Greenberg et al, 1991). The enzyme accumulates to high levels in cells undergoing apoptotic cell death (Fesus et al, 1991; Nagy et al, 1994). In these cells, transglutaminase-mediated protein cross-linking contributes to the formation of apoptotic bodies, the membrane-limited cellular fragments that constitute the remnants of the disintegrating cell (Fesus et al, 1989, 1991). Tissue transglutaminase also appears to be released from connective tissue cells and to become tightly associated with the extracellular matrix (Aeschlimann and Paulsson, 1991; Aeschlimann et al, 1993). The transglutaminase-mediated cross-linking of matrix proteins contributes to the mechanical properties of the specialized matrices involved in osteogenesis (Aeschlimann and Paulsson, 1991, 1994), angiogenesis 
(Barsigian et al, 1991) and wound healing (Bowness et al, 1988).

We are interested in investigating the factors that regulate the expression of tissue transglutaminase in these diverse biological contexts. At least three regulatory processes appear to contribute to the control of tissue transglutaminase in vivo. The first of these is a distinct pattern of tissue specific expression (Thomazy and Fesus, 1989). In the tissues of adult animals the enzyme is particularly abundant in endothelial and smooth muscle cells, erythrocytes, hypertrophic chondrocytes, activated macrophages and cells of the lens epithelium (Thomazy and Fesus, 1989). In embryos and newborn animals the enzyme is expressed in sites of chondrogenesis, in the developing heart, the liver and the choroid plexus (Aeschlimann et al, 1993) and (unpublished observations). Retinoids also exert physiological control over the level of tissue transglutaminase (Chiocca et al, 1988). Retinoids are metabolites of vitamin A that have important physiological functions as morphogens and regulators of cellular proliferation and differentiation (Mangelsdorf, 1994). Vitamin A-deficient rats have a generalized decrease in tissue transglutaminase expression in many, but not all tissues (Verma et al, 1992). Restitution of normal retinoid status in vitamin A-deficient animals or the administration of all-trans retinoic acid (ATRA) to animals with normal retinoid levels results in increased levels of tissue transglutaminase activity in many cells and tissues (Jiang and Kochhar, 1992; Piacentini et al, 1992; Verma et al, 1992). Retinoiddependent regulation of tissue transglutaminase expression can also be observed in vitro. Retinoids increase tissue transglutaminase in many cultured cells and cultured cell lines (Davies et al, 1985; Goldman, 1987; Lichti and Yuspa, 1988; Maddox and Haddox, 1985; Moore et al, 1984). We have shown that retinoids can increase transcription of the tissue transglutaminase gene (Chiocca et al, 1988) and have identified a specific retinoid response element in the $5^{\prime}$ flanking DNA of the mouse tissue transglutaminase gene that may be involved in retinoid-dependent transcriptional control (Nagy et al, 1996).

The induction of apoptosis is a third process associated with increased levels of tissue transglutaminase expression (for reviews see: Fesus et al, 1991; Nagy et al, 1994). The induction of apoptosis of hepatocytes, thymocytes and mammary epithelial cells in intact animals is associated with a large increase in transgutaminase activity in the apoptotic cells (Nemes et al, 1996; Szondy et al, 1997). The induction of apoptosis in myeloid leukemia, neuroblastoma and tracheal epithelial cells is also associated with a dramatic increase in the level of tissue transglutaminase expression (Jiang and Kochhar, 1992; Nagy et al, 1996; Piacentini et al, 1992).

While there is evidence for a dynamic control of the level of transglutaminase expression in diverse physiological contexts, little is known of the molecular mechanisms that regulate tissue transglutaminase gene expression. To address this issue we have isolated a $3.8 \mathrm{~kb}$ segment of $5^{\prime}$ flanking DNA from the mouse tissue transglutaminase gene and have examined its ability to confer appropriate patterns of tissue-specific, retinoidregulated and apoptosis-linked transcriptional activity.
Using both transgenic lineages and stably transfected cell lines we have obtained results that suggest that some, but not all, of the information necessary to confer physiological regulation of the tissue transglutaminase promoter is embedded within the proximal $3.8 \mathrm{~kb}$ of $5^{\prime}$ flanking DNA.

\section{Results}

In order to isolate the $5^{\prime}$ flanking DNA of the mouse tissue transglutaminase gene, a mouse genomic ( $\lambda$-fix) library was screened with a tissue transglutaminase cDNA probe and eight positive phage clones were isolated. One of these clones (2mTG-GC3) hybridized to oligonucleotides derived from the $5^{\prime}$-untranslated region (oligo 50a) and the $5^{\prime}$-end of the coding region (oligo 14a) and was selected for further characterization. Restriction enzyme and nucleotide sequence analysis of $\lambda \mathrm{mTG}-\mathrm{GC} 3$ indicated that it contained the first two exons of the mouse tissue transglutaminase gene and $8 \mathrm{~kb}$ of $5^{\prime}$ flanking DNA (Figure 1A). The transcription start site, identified by $\mathrm{S1}$-protection and anchored PCR analysis of RNA from control and retinoic acid-stimulated cells, was identified as an AG dinucleotide located $66 \mathrm{bp}$ upstream of the initiator codon (data not shown).

A $3.78 \mathrm{~kb}$ segment of the $5^{\prime}$ flanking DNA ( -3710 to +70 ) was subcloned and sequenced (Figure 1B). Comparison of the mouse tissue transglutaminase gene with previously published sequences of the guinea pig and human promoters indicated that all three promoters include a highly conserved TATAA box motif located 25 nucleotides upstream of the transcription start site (Figure 1B). Like the human transglutaminase promoter the mouse transglutaminase promoter has regions with frequent dTdG dinucleotide repeats located -251 to -377 (m dTdG-track 1) and -2296 to -2483 (m dTdG-track 2) in the mouse; the corresponding region to $\mathrm{m}$ dTdG-track1 is -527 to -418 in the human promoter upstream of the transcription start site. As we have previously noted, there is a short segment (61 nt) of nucleotides (HR-1) located $(-1092$ to -1152$)$ in the mouse promoter and -1602 to $-1663 \mathrm{bp}$ upstream in the human promoter that shows a high percentage $(70 \%)$ of identity in the two species (Nagy et al, 1996).

\section{Tissue specific expression}

To determine if the $5^{\prime}$ flanking DNA of the mouse tissue TGase gene contained elements sufficient to direct the tissue specific

A.

Mouse tissue transglutaminase genomic DNA clone ( $($ mTG-GC 3 )

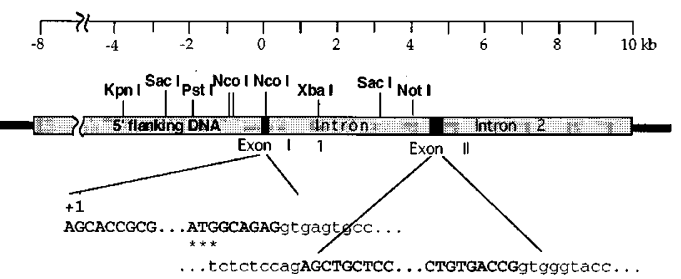


B.

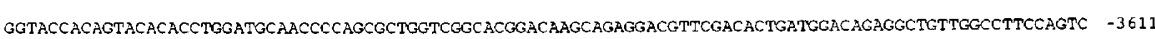
AGAGCATGGCATTCCACACCCTTCACCTCCCCAGCAGCCTGGATATTCCTCTCTGAAGTTTCTGGACTACCCCTTGACATTTCCACCCGTCCCCTGTGCT -3511 AATGGCCCCACTCCACCCATTCAGCCCAGGGGGAGTGGCCCAACTGCCTTGGGTCCCTCACACCAGATTCTGCTCATCCCTGTTAGTCACCATAGAAAARG -3411 GAAAGGCCTCCTAGTACCCCGTCTCTGTCCCACCCTTGGCTCCCCTCCCTTTCATGAAACTCAGACCTCTGGCCCAGGGACCTTTGCCCTACGGGATGG -3311 ACAACGTCTGGGAGCCCAGTCATGCTGTGTGACCTCAGGTCCAATCTCTGAGTCTAATCTTCCCCTTCTTCCTATCCITCCTTGTTATTTTTCCCTCCAG -3211 CCTTTTCTAGCCCTTCTTTTATTTTATTTTTATTTTTTATTTTTTCTGTAATGGTCAAAATGGTTTGGACACCCACAGTCTGTGACCACAGGTCAGATG -3111 CATCAGCCACAGCCCGGAGGACTTCCCTTACTGGGAGGAGACTGACACAGGCCCCTGCTTCCCTAAGGCTGGTAGAGACAAACCTTGTATCTGATGCACT -3011 TGACTATGTGAAGTTAGGCCGTCACCTCACTGCCTCTCTTACATCATTCAACAAATGAGCAAAACTCATGTCGTGAGGCTTCAACAGAGTTCATGGCCAT -2911 ACAACAGTGTCAGTATTGTGACCTGCTTCTTGTCCCCTGGGACCCCCACTTTGTGAGAGAGTACCAGACATCTTCAGAAGTTCCTGGTCATGTITACTGA -2811

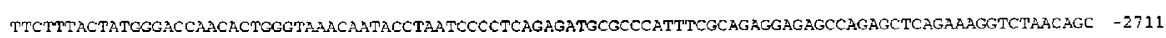
TTGAGGATGCTCCCATAAACAAGAGCTCCATGCACTTCCTGCTCAGACAACTGCACAGTCCGATTTCCCAGCAAAGCATGGCAAAGGGTTCCACACAGTG -2611 CTCTCCAGGGACCTGCAACCCTCCACCACCTTCTCCACACCCCACCACCAAGGCACTTCTGAGATTTTTTTPTTAATTTAAAAAATAAATTAGTTTMATG -2511 ATACATTGGTGTTTTGGCTOCATGTGTGGATGTGTGTGTGTGCATGTGTGTGTGTGTGCATGTGTGTGCATGTGTGTGCGTGTGTGTGTGTGCGTGTGTG -2411 TGTGTSCATGTGTGTGTGTGCATGTGTGTGCGTGTGTGTGTGCATGTGTGTGTGTGCATGTGTGTGTGCGTGTGTGTGTGTGTGTGTGTGTGTGTGTGTG -2311

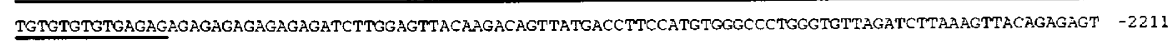
GTAAGTTTCCATGTAGGGACCAGGATTGAGCCCAGGTCTTCTCGAAGAGCAGCCAAGTGCCCCCCAAACCAATAAGCCATTTCTCCAGCCCCCACTTCTG -2111 AGTCTTATCTGCCCCTGTGAGGTATGACACAGCAAGgTCTCATAGACCTTCTCAACTGAACACTGAAGTCAGAGTCAGGCAagGaCCCAAGTCACAGAAC -2011 TGAGAACCAAGTCTCTGATCCAGTTCTGCCCTAGCCCCTGCCTGCCACCTTACTPAAGTCAATGGACCCAGTCCAGTATGGTGGCTTAAGGCCCTOAGCC -1911 ACCACTCAGTTGGCTACAGTTCTGTAGAAAAGACAGAGAAGGATGCAGTGTTGGCCACGGGGTGAGGAGCAAGCCTGCAGTTTCATGCTGAGTCTCTCAC -1811 AGGCACCCCAAATAACTGGTGGGACACCCCCACCATCTGTTCAGTGAATCACAGCTTGCTAATCCTGACCCCACTGGGACCTCTCACAGTGACCCCCATO -1711

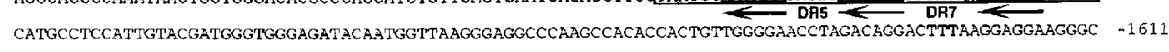
TGCCACCATACAAATAGGAACAAAGGGACATGATGGTAGCAAGAGTGACCAGGCCTCCACATCAGCCCTAGGAGGGCTGGCTGTGGGTTCTATGGTAGTC -I511 ACAGCAGGGGTCTGGATGACTTCATAACATACCTGTTCTCTGAGGCACTTGGGTGGAGACAAGGGTAGGAAGAATGCGTCCTTCTAGGATGGGAA.AGGTC -1411 A.GCGGACACAGCTCTTACCTTCTCTGACAGGGCTGACACTCTTAGGCCAGCCTGGGCTCAAGAGTCCCTAGTGTTGACCACTTPGACTATGCCCCATTCA -1311 AACTCATGAGGAATGAATTCTTGTCCTTATTCCTCACAGGATGGAATGGAGGCCCCCAAAGGCGAGATACCTCCCTGAGCCCCTAACTGTCAGGGGCAGC -1211 ATGCGTAATCAAGAATTGCCTCTTGTCTGGTGGTCACTCGCCAACTCCTCCCTCTGGTECFTCACCAGTCACAGGGAGCAATTTCRATGACAACTACCAT -1111 AAAGIGGGGTCACCCGGG TCCCCAAGGACTGTATGGGCCTTGTCTTGGCACCCTGAGTCACACTCAAATAGAGTCTGGGGGTATCCTCTCAGGTCAAA -1011 GCGGCCAGTCATGCAATGTGTTCCAGAAGAAGGGCTAGAGGGATTCACAGGCCTATGCCTTTTCAAGAAGTCGCCCACTCAGGCTCCATGGTGGTAAGGG -911 AGCTTAGCAAGCTGTCATCAGAGAAGCCAGGATGGAGTTGGTCCATGGGAAGGGTCAGCGGTACGGTGGTCCCTGGGCTCTTCTGGCTGTAGTTCACAGT -811 GGGCTAGCACAGGGAGAGGGATGGGAACAGGGATAGGCAAGAGGATGGGCGAGCAGATGGGTGGGTGGGGGAATTATCGGAaTGAGTGGCTGGGTGGGAC -711 AGGAAGGTATGGGTGTCTGTGGGAGTCCGCGTGCCAGTACCTGCACCCCTGTCTGCCAAGAGTCTATAAGCACCCACATCCAGATACCTACGCATTTGA -611 GGGTTATATGTGGCTTCGTGGAAACCCAGCCCCGTGTCTGCTATGCCTATGTCCTGGCTCTCTAGGTTTGCAATGTGACTTAATGTGGGGATGTTCCTTT -511 AAGCATTGTGTGTCCAAAATTGTTAGTTGATTCTATGGGACTATGGTGTGGATCTCTATGGTTATCTGTCGGCTTGGTTGTGTGTGTGTGTGCCTGTGCA -411 TGTGTGTATEGCATGTTCATGTGTTTGCATGCAGTATGTGTGTGTATAGTATACATGTGTAGATGGTTTATGTGTATGTATGGATGTGGTATGTATGTGC -311 ATACGTATCTGTGTGTGTGTGTGTGTGTGTGTGTGTGTGTGTGTGTGTGTGTGTGGTATATTCATGTATATGTGTGGAGAGGTGCGTGTTCTTGGCCACT $\quad-211$ GGTTTGGCTTGTGGAGCATATCTCTGTGTCTAGGGCATTGGTCACACGCTCCAGGTGTCTGTTCCGAGGTCGTCCTGTGTCCAGCAGGGGGCGCTCCCGG -111 CAGCCTTAGTTCCCGGACAGACAGCCGGGGGTTCCGCCCCGCCCCGCCCGGSGCCCGCCCGCCGCCCGGCCGCCCTGGGCATAATTCGCGCCGCGCG -11 GCTGGTCCGCAGCACCGCGCTGGTGATCCTCGCTTGAGTGTCCCGCTGCGTCTGAGCTGTCGCCGCTAGCCTGGCCATGGCAGAG
+1

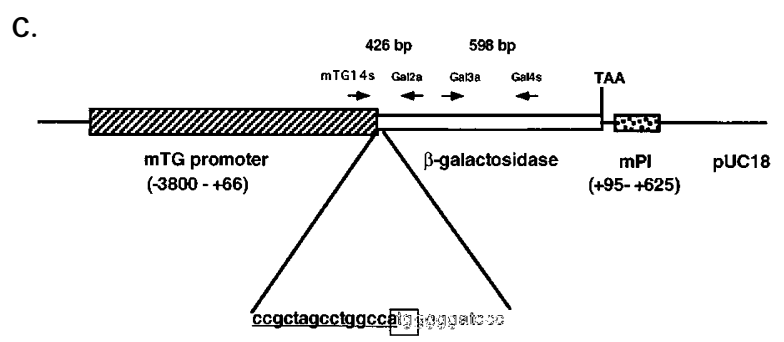

Figure 1 Characterization of the mouse tissue transglutaminase gene. (A) Gene structure. The structure of genomic clone $2 \mathrm{mTG}$-GC3 is shown. The locations of key restriction enzyme sites, exons I and II, introns I and II and the 5'-flanking DNA are shown. The nucleotide sequence of exons I and II flanking the exon/intron boundaries are shown in upper case characters and the intron sequences flanking the boundaries are shown in lower case characters. (B) Nucleotide Sequence of 5'-Flanking DNA. 3785 nucleotides of DNA ranging from +75 to -3110 was sequenced using dideoxy sequencing with oligonucleotide primers. The transcription start site $(+1)$ is identified in bold as is the translation start site $(+67-+69)$. The TATAA-box motif $(-25--29)$ is enclosed in solid boxes, dTdG-tracks (mdTdG-1: $-251--377$ and mdTdG-2: $-2296--2483)$ are underlined. mHR-1 (-1092- -1152) is boxed and residues identical between the mouse and human promoter are shown in black boxes. mTG RRE1 $(-1711--1750)$ is boxed and the orientation of retinoid receptor binding sites DR5 and DR7 are indicated by arrows. (C) Structure of pmTG3.8-LacF. The thin line represents the pUC-18 plasmid sequences, the striped box represents the mouse tissue transglutaminase promoter $(-3785-+66)$, the open box represents the $\beta$-galactosidase structural gene (including the TAA stop codon) and the stippled box represent the murine protamine-1 gene (a source of both an intron and polyadenylation signal). The inset sequence shows the junction between the mouse tissue transglutaminase promoter sequence (in bold) and the $\beta$-galactosidase structural gene (in outline). \#1-\#4 identify the oligonucleotides mTG+1s, GAL2a, GAL3s GAL4a respectively used for the PCR analysis of pmTG3.8-LacF 
A

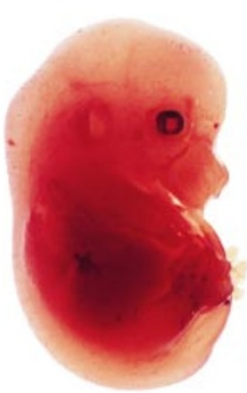

T G- / -

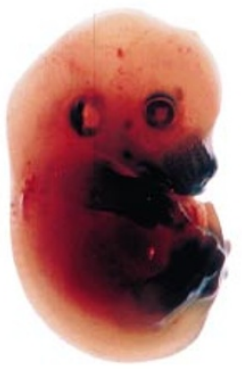

$\mathrm{TG}+/-$
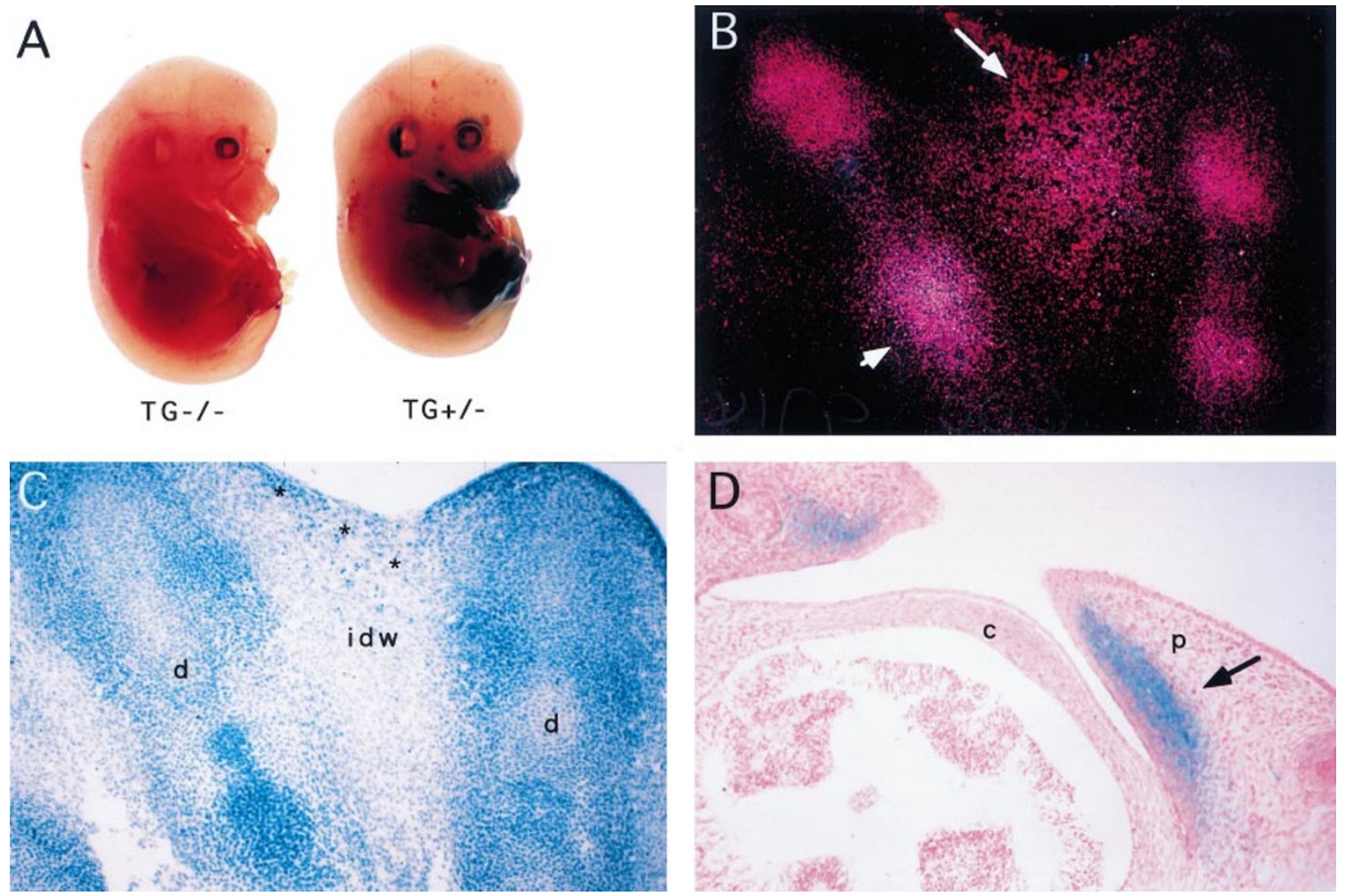

Figure 2 Expression of mTG3.8 LacF in line \#27 in E13.5 embryos. (A) In the transgene negative (TG - / - ) embryo $\beta$-galactosidase staining cannot be detected; whereas it detects transgene expression primarily in the limbs, periorbital and auricular structures in the transgene positive embryo (TG+/-). (B) Histochemical detection of $\beta$-galactosidase activity as revealed by dark field illumination, shows expression of the transgene in the finger cartilage (arrowheads) and the interdigital web (arrows) (C) same field as in (B) in transmitted light to demonstrate the topography of the handplate. Note the presence of apoptotic clusters in the interdigital web (asterisk) (d, cartilage core of phalanges, idw, interdigital web). (D) $\beta$-galactosidase histochemistry shows transgene expression in subepidermal mesenchyme in the eyelid ( $c=c o r n e a ; p=p a l p e b r a)$

expression, we constructed a chimeric reporter gene in which the $3.8 \mathrm{~kb}$ of $5^{\prime}$ flanking DNA was fused to the $\beta$-galactosidase reporter gene (pmTG3.8LacF) (Figure 1C). We generated multiple lineages of mice transgenic for pmTG3.8LacF. Of the 30 candidate animals four were transgene positive by PCR and two expressed $\beta$-galactosidase activity in embryonic tissues. Figure $2 \mathrm{~A}$ demonstrates results obtained with the lineage (\#27) in which there was strongest expression of $\beta$ galactosidase activity in embryonic tissues. Panel A demonstrates the pattern of transgene expression in E13.5 littermates stained for $2 \mathrm{~h}$ with $\mathrm{x}$-gal. The control littermate shows no detectable level of $\beta$-gal activity whereas in the transgenic embryo there is specific expression of $\beta$ galactosidase in auricular and peri-orbital tissues, in the snout and particularly in the developing limbs. To compare the expression of the transgene and the endogenous tissue transglutaminase gene we carried out a detailed analysis of the distribution of $\beta$-galactosidase activity (Figure 2) and tissue transglutaminase immunoreactivity (Figure 3 ) in the limb structures of the E13.5 mouse embryo. Figure 2B shows the distribution of $\beta$-galactosidase reaction product detected by dark field microscopy in the handplate of a E13.5 lineage \#27 embryo. The $\beta$-galactosidase reaction product (bright purple grains) is prominent in the core of the developing digits and in the wedge-shaped area corresponding to the interdigital web.
These areas of transgene expression are coincident with sites of expression of the endogenous tissue transglutaminase gene. Figure $3 \mathrm{~A}$ shows a longitudinal section through the cartilage precursor of a phalangeal bone from a E13.5 mouse embryo stained with anti-tissue transglutaminase antibody. Tissue transglutaminase is present in the precartilagenous blastema (data not shown) and in the hypertrophic chondrocytes, and in the periarticular mesenchyme. The enzyme is absent from the prolifrating chondrocytes, Figure $3 \mathrm{~B}$ shows the same field in phase contrast to demonstrate the tissue structures. Comparison of the expression of the transgene and endogenous transglutaminase in other sites of chondrogenesis such as those ocurring in the axial skeleton, also revealed concordance of transglutaminase and transgene expression (Figure $3 \mathrm{E}$ and data not shown). Immunostaining of the interdigital mesenchyme (Figure $3 C$ ) revealed an increased expression of tissue transglutaminase with focal accumulation of the enzyme associated with clusters of apoptotic cells (Figure 3D). These latter structures appeared to represent tissue macrophages containing numerous remnants of apoptotic mesenchymal cells.

The prominent blue staining of the proximal limbs, snout and periorbital tissues seen in macroscopic views of E13.5 embryos (Figure 2A) is due to intense expression of $\beta$ galactosidase activity in zones of mesenchymal cells 
underlying the epidermis in these regions. Figure 2D illustrates the localized expression of the $\beta$-galactosidase transgene in the eyelid of an E13.5 mouse embryo. Although tissue transglutaminase is present in the craniofacial and limb mesenchyme, its levels are uniform throughout the tissue, it does not show evidence of localized increases in expression that characterize the pattern of transgene activity. There are also some tissues in which tissue transglutaminase is expressed but in which no $\beta$-galactosidase activity can be detected in transgenic embryos. For instance tissue transglutaminase is expresed both in the liver and heart of the E13.5 mouse embryo (Figure 3F and data not shown). However even in heavily overstained transgenic embryos, no $\beta$-galactosidase activity can be detected in either tissue (data not shown).

\section{Retinoid regulated expression}

The goal of these studies was to determine if retinoid regulated expression of the intact tissue transglutaminase gene was replicated by the $3.8 \mathrm{~kb}$ promoter. To address this problem we generated HeLa cell lines stably transfected with either pmTG3.8-LacF or a promoterless control vector (placF). By then measuring transglutaminase and $\beta$-galactosidase activities we could compare the activation of the endogenous transglutaminase promoter and its cloned


Figure 3 Detection of tissue transglutaminase by immunohistochemistry in E13.5 mouse embryos. (A) Hypertrophic chondrocytes in the phalangeal cartilage show strong labeling by immunfluorescence staining (arrow). Moderate labeling in the peri-articular mesenchyme and the undifferentiated dermal mesenchyme. (B) Same field as A in transmitted light to demonstrate the topography of the handplate. (C) Focal accumulation of transglutaminase in the interdigital web corresponding to apoptotic clusters (arrowhead) (immonofluorescent staining). (D) Same field as C in transmitted light to demonstrate the presence of apoptosis in the interdigital web, note the granular appearance of apoptotic 'clusters' (boxed) (E) High level of transglutaminase expression in the hypertrophic chondrocytes of the developing vertebrae (arrowhead). Note vascular endothelial labeling at arrow, avidin-biotin peroxidase, hematoxylin counterstaining. (F) High level of tissue transglutaminase can be detected in the myocardium and pericardial lining ( $a=a t r i u m ; ~ p=p e r i c a r d i u m)$, avidin-biotin peroxidase, hematoxylin counterstaining 
counterpart. HeLa cells were co-transfected with the a plasmid conferring Hygromycin resistance and either pmTG3.8-LacF or pLacF. Hygromycin resistant clonal lines were isolated and two lines, clone 4-2 (transfected with pmTG3.8-LacF) and clone C-4 (transfected with the control pLacF) were selected for further characterization. Quantitative slot blot analysis of DNA from these cell lines revealed that clone 4-2 contains seven copies of integrated pmTG3.8-LacF and C-4 contains four copies of pLacF (data not shown).

To test the retinoid-responsiveness of the integrated mouse tissue transglutaminase promoter, RNA from control and ATRA-treated 4-2 and C-4 cells was screened for $\beta$ galactosidase transcripts by RT-PCR (Figure 4A). In control cells $(\mathrm{C}-4)$ no $\beta$-galactosidase transcripts were detected in either the presence or absence of ATRA (Figure 4A lanes 4 and 5). In the 4-2 cell line a basal level of $\beta$-galactosidase transcript was detected in untreated cells that was increased greatly by the addition of ATRA (Figure 4A lanes 2 and 3).

To compare the retinoid-inducibility of the endogenous tissue transglutaminase promoter in the HeLa cells with the transfected mouse tissue transglutaminase promoter we measured the retinoid-dependent induction of transglutami- nase and $\beta$-galactosidase activity in the 4-2 cell line (Figure $4 \mathrm{~B}$. In 4-2 cells the basal level of transglutaminase activity (0.036 $\mathrm{pmols} / \mathrm{min} / \mathrm{mg}$ ) was increased 4.3 -fold by the addition of ATRA. This induction is similar to the induction of transglutaminase activity in mock transfected HeLa cells and in the control C-4 cell line (data not shown). In 4-2 cells there was a basal level of $\beta$-galactosidase activity (0.7 RLU/mg) indicating that, like the endogenous transglutaminase promoter, the transfected transglutaminase promoter showed some constitutive activity in HeLa cells. Addition of ATRA resulted in a 2.2-fold increase in $\beta$ galactosidase activity over controls. These stable transfection experiments demonstrated that the $3.8 \mathrm{~kb}$ mouse tissue transglutaminase promoter fragment is retinoid inducible and the level of induction in response to ATRA is comparable to the induction of the endogenous tissue transglutaminase gene.

The effects of retinoids are mediated by two classes of retinoid receptors (RARs and RXRs) that participate in multiple hormone signaling pathways (Mangelsdorf et al, 1994). HeLa cells contain both RAR's and RXR's (Table 2). To evaluate the role of these receptors in the activation of both the endogenous HeLa cell transglutaminase

A

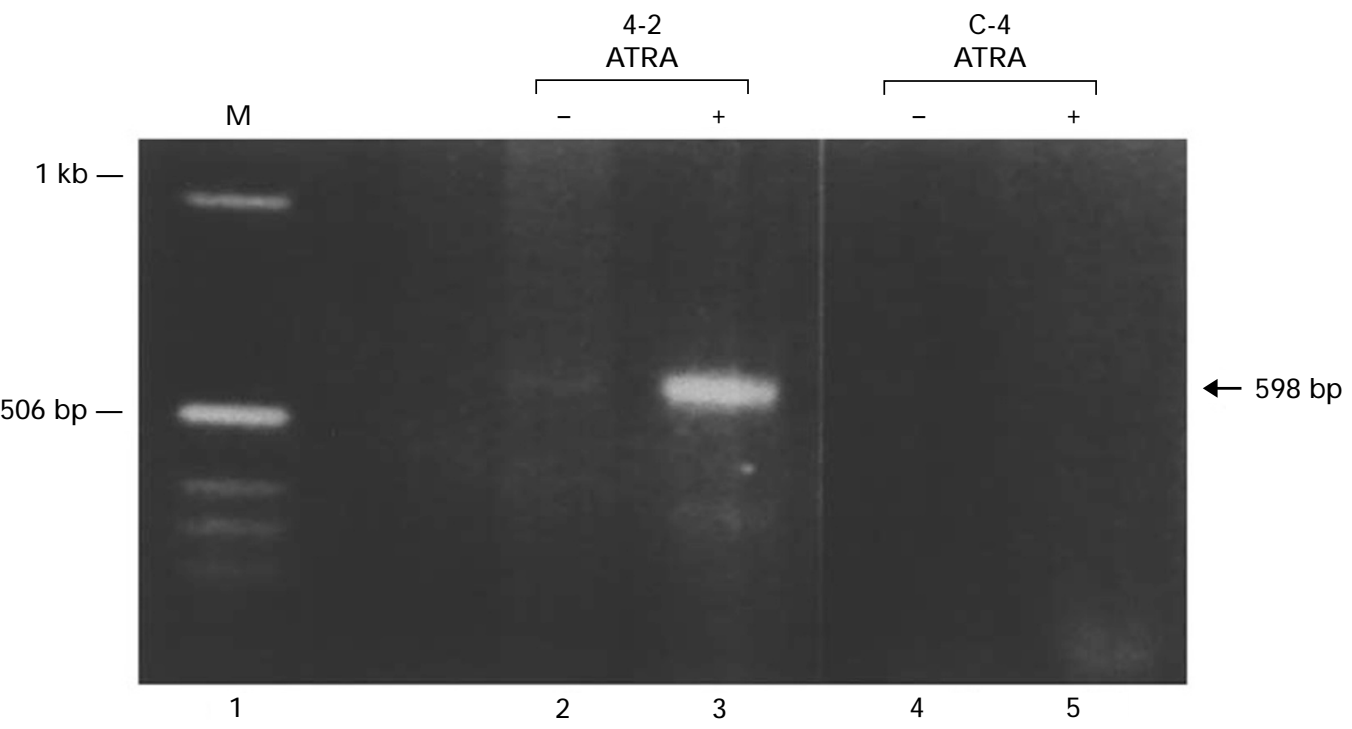

B
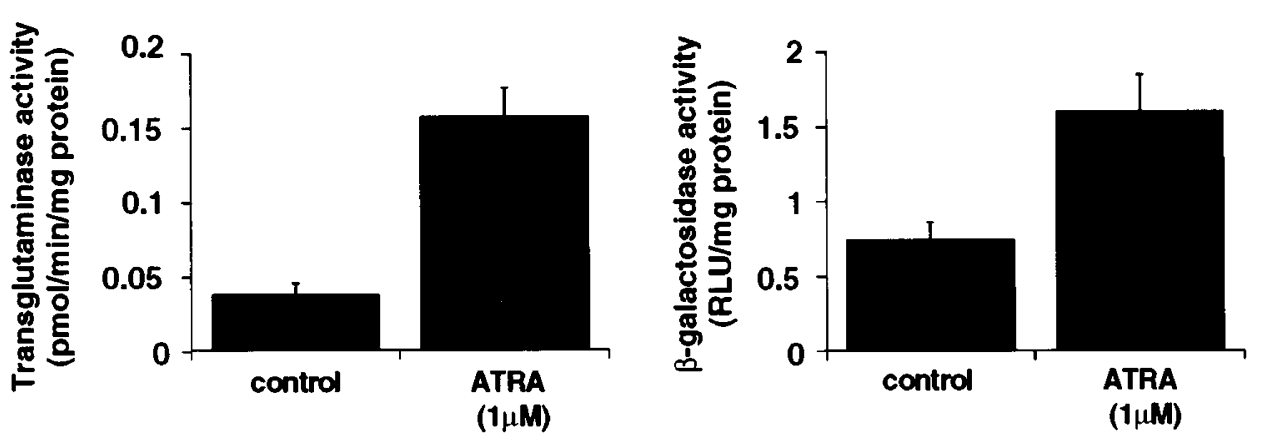
promoter and the transfected mouse tissue transglutaminase promoter, 4-2 cells were treated with retinoid receptor selective analogues and the induction of transglutaminase and beta-galactosidase activities were measured. AM-80 is an RAR-selective retinoid (Fukasawa et al, 1993), LG1069 is RXR-selective (Boehm et al, 1994; Kurokawa et al, 1994). Both AM-80 and LG1069 induced a dose-dependent increase in transglutaminase and $\beta$ galactosidase activity in 4-2 cells (Figure 4C). In both assays the dose-response curve for LG1069 parallels the AM-80 curve but is shifted $1 / 2-1 \log$ units to the right indicating that the RXR-specific retinoid is less potent than the RAR-specific compound in activating both the endogenous and transfected transglutaminse promoters. Both compounds induced a comparable maximal induction of both transglutaminase and $\beta$-galactosidase activities. This level of activity was very similar to the maximal induction achieved with ATRA (compare Figure 4C with $4 \mathrm{~B})$. These studies indicate that both the endogenous human tissue transglutaminase gene and the transfected tissue transglutaminase promoter are equivalently activated by both RAR-dependent and RXR-dependent retinoid signaling pathways.

\section{Apoptosis-linked expression}

One of the lineages of mice transgenic for the pmtg3.8 Lac F reporter gene (\#26) showed a much lower and more restricted pattern of transgene expression than the \#27 lineage. It appears as a quantitative difference due to different integration sites. If E11.5 embryos of the lineage \#26 are stained for $24 \mathrm{~h}$ with $\mathrm{x}$-gal the null animals show no $\beta$ galactosidase staining but the transgenic animals showed $\beta$ galactosidase activity along the anterior edge of the proximal limb bud, in the craniofacial processes and in the mesenchyme of the developing cranium (Figure $5 \mathrm{~A}$ ). Detailed evaluation of the anterior limb bud in the E11.5 embryo showed intense staining of cells in the region of the anterior necrotic zone with the faint appearance of transgene positive cells in the developing posterior necrotic zone and apical ectodermal ridge (AER) (Figure 5B). By day 12.5 staining of the posterior margin of the anterior limb becomes prominent and the anterior necrotic zone of the hind limb becomes positive for transgene expresson (data not shown). By E13.5 transgene expression in the limb is concentrated in the posterior necrotic zone, in the interdigital web and the apical ectodemal ridge (AER) (Figure 5C and D). Panel D

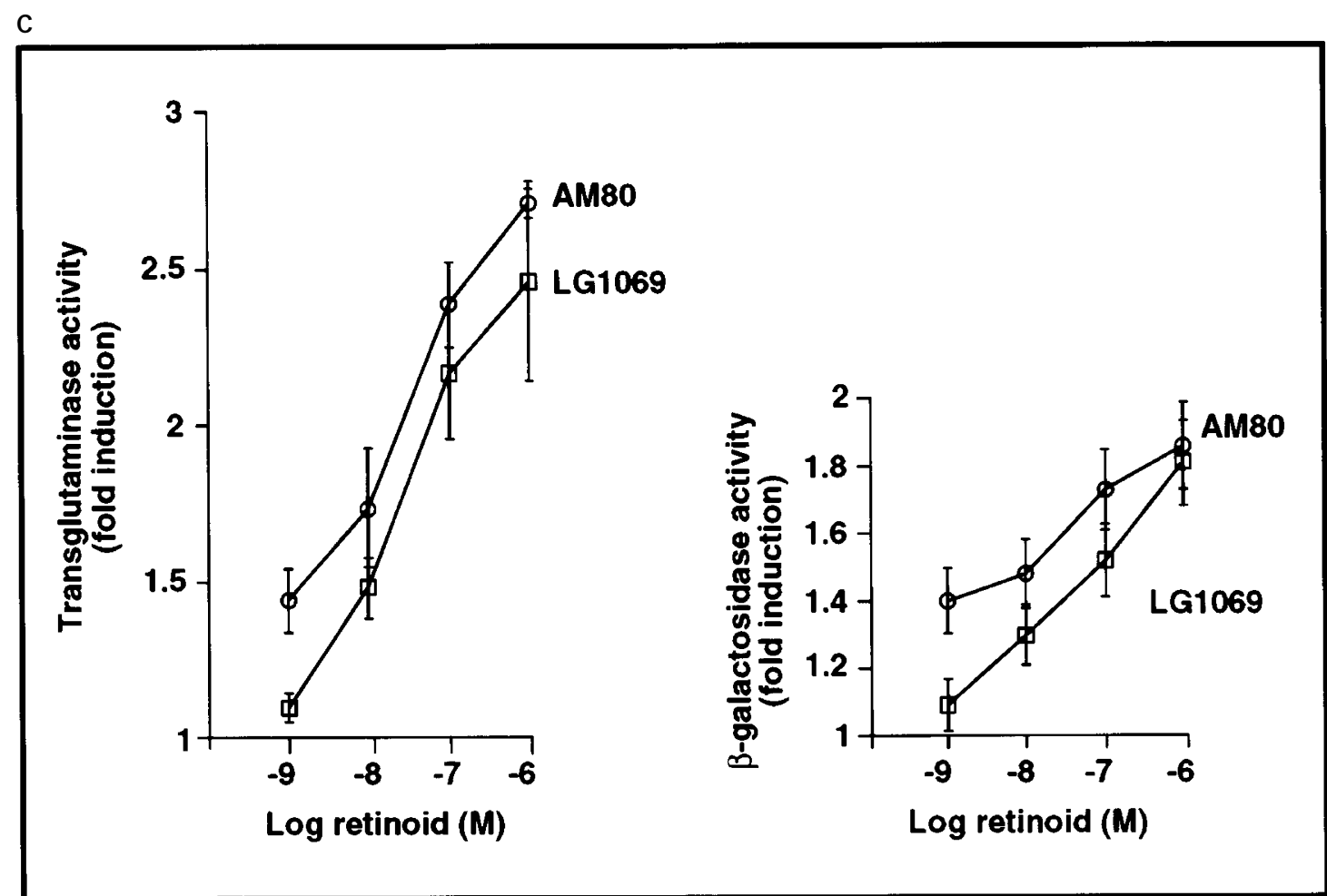

Figure 4 Effect of all-trans RA (ATRA) on $\beta$-galactosidase expression and transglutaminase activity of stably transfected HeLa cell lines. (A) RT - PCR. RNA was prepared from HeLa cells stably transfected with either pLacF (C-4) or pmTG3.8-LacF (4-2) that had been exposed to ATRA or control media for 72h. The RNA was subject to RT - PCR with oligonucleotide primers (GAL3s and GAL4a) specific for $\beta$-galactosidase under conditions described in Materials and Methods. The RTPCR products were fractionated on a $2 \%$ agarose gel and stained with ethidium bromide. The arrow on the right indicates the mobility of the anticipated $598 \mathrm{bp} \beta$ galactosidase amplified fragment. (B) Transglutaminase and $\beta$-galactosidase activity. HeLa cells stably transfected with pmTG3.8-LacF (4-2) were treated with control media or ATRA $(1 \mu \mathrm{M})$ for $72 \mathrm{~h}$. Cells were then lysed and the transglutaminase and $\beta$-galactosidase activities were determined by enzymatic and chemiluminescence assays respectively as described in Materials and Methods. (C) Effect of AM-80 and LG1069 on the transglutaminase and $\beta$-galactosidase activity of HeLa 4-2 cells. HeLa cells stably transfected with pmTG3.8-LacF (4-2) were treated with varying concentrations of AM-80 or LG1069 for 48 h. The transglutaminase activity and $\beta$-galactosidase activity were determined by enzymatic assays. Values shown are the fold increase in enzymatic activity in the retinoid-treated cells compared to control cells treated with solvent 
showed a magnified view of the E13.5 embryo limb that demonstrates the presence of foci of $\beta$-galactosidase positive cells in both the posterior necrotic zone and in the interdigital web. The expression of the transgene is restricted to the zones of apoptosis in the interdigital webs. Panel $E$ (longitudinal section) and G (cross-section) show darkfield micrographs of $\mathrm{x}$-gal stained sections that transects two digits and the connecting interdigital region. It is clear that the pattern of $\beta$-galactosidase expression, detected by the bright purple granular staining is restricted to the interdigital mesenchymal cells. This is the same region in which clusters of transglutaminase positive cells are detected by immunohistochemical localization (Figure $3 \mathrm{C}$ ). A bright field micrograph of the same region stained with $\mathrm{x}$-gal reveals that the $\beta$ galactosidase activity is associated with cells showing a clear apoptotic morphology as well as adjacent cells that do not show the morphologic hallmarks of apoptosis (Figure 5F). Interestingly the remnants of apoptotic cells within tissue phagocytes do not show histochemical evidence of $\beta$ galactosidase activity. The pattern of transgene expression of the \#26 lineage appears to be coincident with cells undergoing apoptosis suggesting that the $3.8 \mathrm{~kb} \mathrm{mTG}$ promoter includes sequences necessary for apoptosis linked expression.

\section{Discussion}

The goal of these studies is to identify the cis regulatory regions controlling of tissue transglutaminase gene expression. Before embarking on detailed analysis of the

Table 1 Sequence and location of oligonucleotides

\begin{tabular}{|c|c|c|}
\hline Name & Sequence & Source \\
\hline $\mathrm{mTG}+14 \mathrm{~s}$ & $\begin{array}{l}5^{\prime}-\text { TGATCCTC } \\
\text { GCTTGAGTGTCC-3' }\end{array}$ & $\begin{array}{c}\mathrm{mTG}+14 \text { to }+33 \\
\text { sense }\end{array}$ \\
\hline mTG14a & $\begin{array}{l}5^{\prime}-\text { TTCGAGGGC } \\
\text { CGTGGCTACGA-3' }\end{array}$ & $\begin{array}{c}\mathrm{mTG}+199 \text { to }+218 \\
\text { antisense }\end{array}$ \\
\hline mTG18a & $\begin{array}{l}5^{\prime}-\mathrm{AATGGCCGT} \\
\text { GACCACCACACG-3' }\end{array}$ & $\begin{array}{l}\mathrm{mTG}+115 \text { to }+135 \\
\text { antisense }\end{array}$ \\
\hline mTG19a & $\begin{array}{l}5^{\prime}-\mathrm{CCTCGCTTG} \\
\text { AGTGTCCCG-3' }\end{array}$ & $\mathrm{mTG}+18$ to +35 \\
\hline mTG22s & $\begin{array}{l}5^{\prime}-\mathrm{CCCGCACT} \\
\text { GTCAGCTACAA-3' }\end{array}$ & $\begin{array}{c}\mathrm{mTG}+1598 \text { to } \\
+1616 \\
\text { sense }\end{array}$ \\
\hline mTG53a & $\begin{array}{l}\text { 5'-CGGTGCTGTGACCGGC } \\
\text { CCAGATCCCAGTGAAG-3' }\end{array}$ & $\begin{array}{c}\mathrm{mTG}+243 \text { to }+274 \\
\text { antisense }\end{array}$ \\
\hline mTG-267s & $\begin{array}{l}\text { 5'-atatgaattcGGTATA } \\
\text { TCATGTATAGTG-3' }\end{array}$ & $\begin{array}{c}\mathrm{mTG}-238 \text { to }-285 \\
\text { sense }\end{array}$ \\
\hline $\mathrm{mTG}+16 \mathrm{a}$ & $\begin{array}{l}\text { 5'-TAGGAGCGAACTC } \\
\text { ACAGGctcgagatcttaag-3' }\end{array}$ & $\begin{array}{c}\mathrm{mTG}+16 \text { to }+33 \\
\text { antisense }\end{array}$ \\
\hline mTG50a & $\begin{array}{l}5^{\prime}-\mathrm{TAGCGGCG} \\
\text { ACAGCTCAGAC-3' }\end{array}$ & $\begin{array}{l}\mathrm{mTG}+40 \text { to }+58 \\
\text { antisense }\end{array}$ \\
\hline GAL2a & $\begin{array}{l}5^{\prime}-\text { ATAATTCGC } \\
\text { GTCTGGCCTTC-3' }\end{array}$ & $\begin{array}{c}\beta \text {-Gal } \\
\text { antisense }\end{array}$ \\
\hline GAL3s & $\begin{array}{l}5^{\prime}-\mathrm{CCTGTATGTG} \\
\text { GTGGATGAAGC-3' }\end{array}$ & $\begin{array}{l}\beta \text {-Gal } \\
\text { sense }\end{array}$ \\
\hline GAL4a & $\begin{array}{l}5^{\prime}-\text { ACGTTCAT } \\
\text { ACAGAACTGGC-3' }\end{array}$ & $\begin{array}{c}\beta \text {-Gal } \\
\text { antisense }\end{array}$ \\
\hline $\begin{array}{l}\text { Hybrid } \\
\qquad \mathrm{dT}_{17}- \\
\text { adaptor }\end{array}$ & $\begin{array}{l}\text { 5'-тTтTтTтTттттттTтT } \\
\text { AAGCAGCTGAGCTCAG-3' }\end{array}$ & \\
\hline $\begin{array}{l}\text { Adaptor } \\
\text { primer }\end{array}$ & $\begin{array}{l}\text { 5'-TTAAGCAGC } \\
\text { TGAGCTCAG-3' }\end{array}$ & \\
\hline
\end{tabular}

individual elements that participate in the physiological control of the expression of this enzyme we initiated studies to delineate the general boundaries of the regulatory regions of this promoter. Our concerns are based on the observation that for many retinoid regulated genes, the regions of the promoter responsible for controlling gene expression can be located far from the core promoter sequences. For instance sequences involved in controlling CRABPII gene expression have been localized far upstream in the CRABPII promoter (Astrom et al, 1994); the retinoid regulatory regions of the hox1.6 gene are present in the 3' flanking DNA (Langston and Gudas, 1992). In human keratinocyte Tgase gene, retinoid regulated transcriptional activity has been associated with sequences embedded in the first intron ( $R$. Polakowska personal comm.). To gain some insight into the extent to which regulation of the tissue transglutaminase gene is dependent on sequences localized within the $5^{\prime}$ flanking DNA, we isolated a segment of the promoter and then used both transfection and transgenic studies to determine the extent to which the isolated promoter region replicates the regulatory activity of the intact gene. In particular we have examined the extent to which $3.8 \mathrm{~kb}$ of the $5^{\prime}$ flanking DNA can direct appropriate patterns of retinoid-regulated, tissue-specific and apoptosis-linked expression.

\section{Transfection studies}

Previous studies from our laboratory have demonstrated that retinoids can regulate the transcription of the tissue transgutaminase gene (Chiocca et al, 1988). Using cotransfection assays in which we overexpressed retinoid and transglutaminase-based reporter constructs we identified a region of the promoter that was a candidate retinoid response element (Nagy et al, 1996). An unusual feature of this transglutaminase RRE was that although it included a canonical DR5 (direct repeats separated by five nucleotides) retinoid response element (Figure 1B) it was activated by both RAR and RXR signaling pathways (Nagy et al, 1996). Transient transfection experiments can be misleading because the combination of supraphysiological levels of receptors and target DNAs can unmask regulatory activities not expressed when receptors and target genes present in cells at physiological levels. To determine if the intact transglutaminase gene and the

Table 2 Retinoid receptor profile of HeLa cells

\begin{tabular}{lc}
\hline Retinoid receptor & $\begin{array}{c}\text { Relative amount } \\
\text { (normalized densitometric units) }\end{array}$ \\
\hline $\operatorname{RAR} \alpha$ & 26.9 \\
$\operatorname{RAR} \beta$ & $<1.2^{*}$ \\
$\operatorname{RAR} \gamma$ & 15.9 \\
$\operatorname{RXR} \alpha$ & $<1.2^{*}$ \\
$\operatorname{RXR} \beta$ & 24.2 \\
$\operatorname{RXR} \gamma$ & N.D. \\
\hline
\end{tabular}

*Below lower limit of detection. N.D. not determined. RNase protection analysis was performed as described in Materials and Methods 
transglutaminase promoter were equivalently activated in vivo we established stably transfected cell lines in which the endogenous retinoid receptors were used to drive the transcription of both the endogenous transglutaminase gene (two copies) and a very few (seven copies) of a stably integrated transglutaminase promoter-regulated reporter construct.

The results we obtained demonstrated that both the endogenous gene and the transfected promoter are equivalently activated by both RAR and RXR signaling
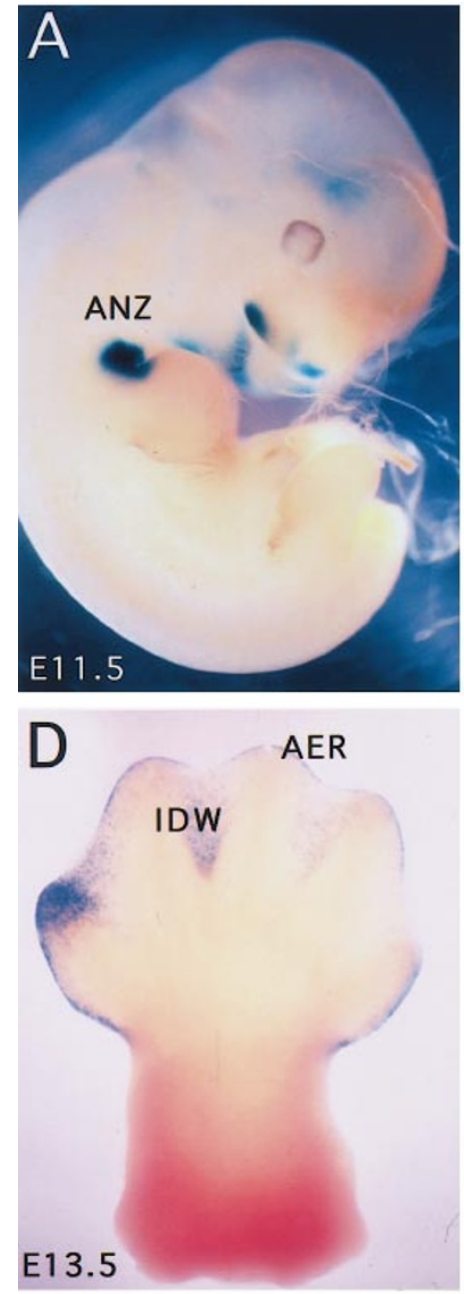
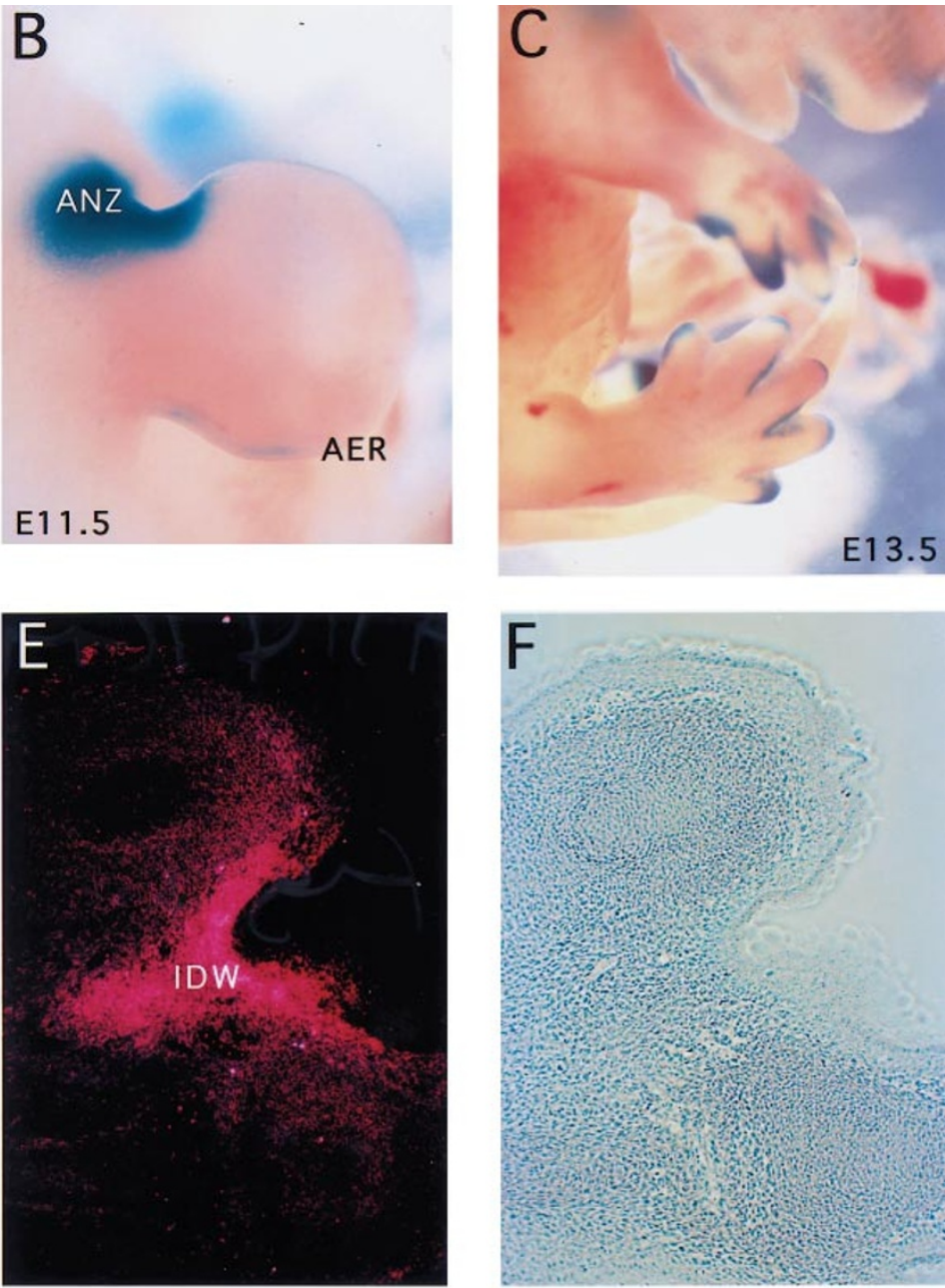

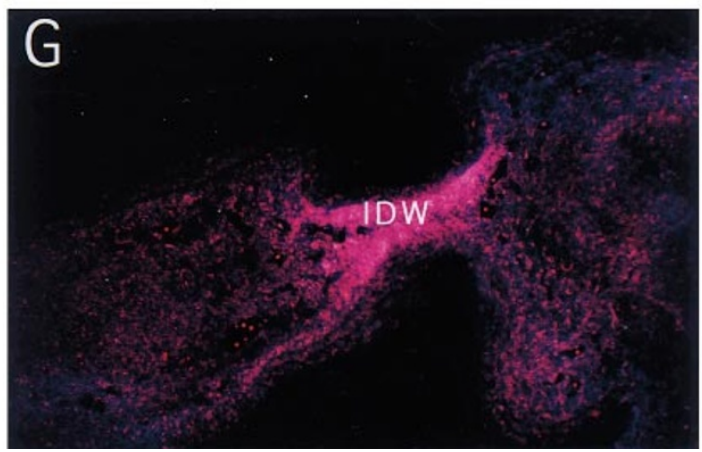

Figure 5 Expression of mTg3.8 LacF in E11.5 and E13.5 line \#26 embryos. (A) $\beta$-galactosidase confined to anterior border of forelimb, apical ectodermal ridge, facial processes and cranial mesenchyme at E11.5. (B) Close-up of forelimb of E11.5 embryo, showing expression of the transgene in the anterior necrotic zone (ANZ), apical ectodermal ridge (AER). (C) Transgene expression at E13.5 embryo is localized to the distal parts of the limbs where it is concentrated over the tips of the fingers and the interdigital areas. (D) Close up of hindlimb of a E13.5 embryo, expression of the transgene specifically detects areas of programmed cell death in the interdigital webs (IDW) and along the edges of the footplate, the remnants of AER at the tips of the fingers also express the transgene. (E and G) Detection by dark field microscopy of $\beta$-galactosidase expression shows reaction product uniformly distributed in the interdigital mesenchyme (IDW) of E13.5 limbs (E, section in the antero-posterior plane, G, transverse section (dorso-ventral plane). (F) Same field as E in transmitted light to demonstrate the topography 
pathways. This finding suggests that all of the components necessary for retinoid regulated expression of the transglutaminase gene are embedded within the $3.8 \mathrm{~kb}$ flanking DNA.

In certain biological systems, such as tracheal epithelial cells, RAR-specific retinoids activate transglutaminase gene expression whereas RXR-specific retinoids do not (Jiang and Kochhar, 1992). In myeloid leukemia cells and HeLa cells both classes of selective retinoids induce expression of the enzyme (Nagy et al, 1996). Since the transglutaminase promoter can be regulated by both signaling pathways it is likely that differences in different biological systems in the inducibility of the enzyme reflects alterations in the activity of retinoid-signaling pathways in different biological contexts. The recent discovery of families of coupling factors that mediate the diverse effects of retinoids on gene activation and repression may account for some of these observed differences (Chen and Evans, 1995; Horlein et al, 1995). Identification of the receptor complexes and co-activator proteins that mediate the effects of RAR- and RXR-signaling pathways on transglutaminase gene expression may shed new light on these processes.

\section{Cartilage}

In the developing mouse embryo high levels of tissue transglutaminase accumulate in sites of chondrogenesis. In the limb both the pre-cartilaginous blastema and hypertrophic chondrocytes express high levels of the enzyme whereas the level of the enzyme is low in the intervening zone of the proliferating chondrocytes (Aeschlimann et al, 1993). In the \#27 lineage the transglutaminase transgene is clearly expressed in both the precartilagenous blastema and hypertrophic chondrocytes, like the endogenous enzyme, it is not expressed in the proliferating cells. This pattern of colocalization is not restricted to the limb but is also apparent in the development of the axial skeleton. The match between the sites of transgene and transglutaminase expression demonstrate that the $3.8 \mathrm{~kb}$ transglutaminase promoter accurately directs the expression of transglutaminase in chondrogenic cells.

It is possible that the expression of transglutaminase in chondrogenic cells reflects the role of retinoids in regulating chondrogenic differentiation. Studies from a number of laboratories have shown that retinoids play a critical role in regulating chondrogenic differentiation and particularly the patterns of gene expression of hypertrophic chondrocytes (Cash et al, 1997; Oettinger and Pacifici, 1990; Pacifici et al, 1991; Ywamoto et al, 1993, 1994). Retinoids also induce tissue transglutaminase expression in cultured chondrocytes (V. Gentile personal comm.). The fact that the $3.8 \mathrm{~kb}$ transglutaminase promoter fragment faithfully reflects retinoid-regulated expression of the intact transglutaminase gene may explain the tissue-specific expression of the transgene in chondrogenic tissues.

\section{Apoptosis}

Several studies have suggeted that tissue transglutaminase is both induced and activated in cells undergoing apoptotic cell death (Aeschlimann and Paulsson, 1994; Fesus et al, 1987, 1989, 1991; Jiang and Kochhar, 1992; Kochhar et al, 1993; Nagy et al, 1994, 1996; Piacentini et al, 1992a,b; Piacentini and Melino, 1994). Since the interdigital web of the E13.5 mouse embryo is a region undergoing extensive apoptosis, we examined in some detail the expression of the transglutaminase transgene in this tissue. In the \#27 lineage in spite of the fact that there is a generalized expression of the transgene in the limb mesenchyme there is clearly increased expression of $\beta$-galactosidase activity in the interdigital mesenchymal cells. As was demonstrated in Figure $2 \mathrm{~B}$ the level of $\beta$-galactosidase in the interdigital web is comparable to that in the regions of chondrogenesis. In the \#26 lineage at E13.5 expression of the transgene is effectively limited to the interdigital mesenchymal cells in both transgenic models $\beta$ galactosidase activity is distributed throughout the interdigital mesenchyme. Within the limits of histochemical staining there is no marked difference in the level of $\beta$-galactosidase activity in interdigital mesenchymal cells showing a normal morphology and those undergoing apoptosis. These studies suggest that there may be a generalized increase in the expression of the transglutaminse transgene in the region of cells destined to undergo apoptosis rather than a specific activation of the transgene during the progress of the apoptotic program. This observation parallels recent observation in the developing chick limb (E7.5) that increased levels of transglutaminase mRNA detected by in situ hybridization were detected uniformly in the interdigital web (unpublished observations).

The uniform expression of the transglutaminase transgene in the interdigital mesenchyme is paralleled by a generalized expression of the transglutaminase enzyme in the same tissue (compare Figure 2B, 5E, G and Figure $3 C)$. There is evidence of high levels of transglutaminase protein associated with clusters of apoptotic cells but this immunoreactivity may reflect high levels of the enzyme in activated macrophages rather than in the remnants of the apoptotic mesenchymal cells. Activated macrophages are known to express high levels of transglutaminase activity (Johnson and Davies, 1986). It is possible that the induction and activation of transglutaminase during interdigital apoptosis is a two step process in which a generalized induction of the enzyme in the region undergoing apoptosis is followed by a specific activation of the latent enzyme during the apoptotic process.

The \#26 lineage of transgenic mice shows a remarkably restricted pattern of transgene expression that parallels regions of apoptosis that occur during different stages of limb development. In the earliest embryos examined expression is restricted to the anterior margins of the anterior limb bud. This region corresponds to the well characterized region of morphogenic apoptosis, the anterior necrotic zone (ANZ) described in detail in the chick. In the \#26 lineage expression is subsequently localized in the posterior and more distal aspects of the anterior limb bud. Ultimately expression of the transgene is limited to the interdigital zones and the posterior aspects of the developing hand-plate. The same pattern of transgene expression occurs in the hind-limb but is delayed $24 \mathrm{~h}$ relative to the anterior limb. The orderly and progressive expression of the transglutaminase transgene in the mouse limb and its 
remarkable coincidence with regions of apoptosis suggests this lineage may provide a very useful model for investigating programmed cell death during limb development.

\section{Tissue-specific expression}

The goal of these studies was to determine whether $3.8 \mathrm{~kb}$ of the tissue transglutaminase promoter included the regulatory information sufficient to direct the tissue-specific expression of the transglutaminase gene. While there is a general agreement between the expression of the transgene and transglutaminase at regions of chondrogenesis and sites of apoptosis in the limb, there are clearly sites where such parallelism cannot be found. Tissue transglutaminase is expressed in embryonic heart and liver but we detected no evidence of transgene expression in either of these tissues. This lack of detection $\beta$-galactosidase activity was not due to an inability of $x$-gal to penetrate the tissues since even sections of liver and heart stained with X-gal post-sectioning failed to show any evidence of $\beta$-galactosidase activity. The lack of transgene expression in these tissues could reflect an ability to detect low levels of constitutive transgene expression. We do not believe that this is the case since the \#27 lineage shows very robust transgene expression in mesenchymal tissues and even heavily overstained embryos failed to demonstrate $\beta$-galactosidase activity in the liver or the heart. A more likely explanation is that $3.8 \mathrm{~kb}$ transglutaminase promoter lacks sequences present in the endogenous gene that are necessary for the specific expression of tissue transglutaminase in these tissues. This possibility has the interesting implication that this cisregulatory sequences necessary for the expression of tissue transglutaminase in regions of chondrogenesis and apoptosis are different from those regulating the expression of the enzyme in parenchymal tissue such as liver and heart. The induction of vitamin A deficiency resulted in a decrease in transglutaminase activity in many but not all tissues (Verma et al, 1992). Transglutaminase expression in the kidney for instance, in adult animals, is independent of retinoid status whereas transglutaminase expression in the lung and trachea are very dependent on endogenous retinoids. It is likely that multiple regulatory factors control the expression of tissue transglutaminase in embryonic tissues, some of these require sequences in the proximal promoter whereas others, such as those that control expression of the enzyme in hepatic or myocardial cells may require quite different regulatory regions of the gene.

\section{Summary}

The results we have obtained suggest that the $3.8 \mathrm{~kb}$ segment of promoter flanking the $5^{\prime}$-end of the tissue transglutaminase gene contains all of the cis-regulatory sequences necessary for retinoid regulated transcriptional activity. This may explain why the transglutaminase transgene is appropriately expressed in tissues such as cartilage and the limb mesenchyme where retinoids have been implicated in the physiological control of gene expression (Helms et al, 1996; Kastner et al, 1995; Kochhar et al, 1993; Ywamoto et al, 1994). These sites are not simply sites of generic retinoid-regulated gene expression however since a different retinoid regulated reporter transgene, the RAR $\beta$-lac $Z$ transgene, shows different sites of expression during limb development in the mouse (Mendelsohn et al, 1991). The RAR $\beta$-lac $Z$ transgene is expressed in regions where $\operatorname{RAR} \beta$ is present whereas the pattern of expression of transglutaminase transgene is similar to the sites of expression of both RAR $\alpha$ and RAR $\gamma$ (Dolle et al, 1989). Thus the different patterns of expression of retinoid regulated genes during morphogenesis may reflect subtle differences in the ability of different retinoid receptors to activate their expression in vivo.

The results we have obtained suggest that the $3.8 \mathrm{~kb}$ transglutaminase promoter may be suitable for investigating some aspects of the regulation of transglutaminase expression whereas it may not be suitable for others. It seems likely that this region is appropriate for detailed evaluation of retinoid-linked regulatory proceses and processes associated with the induction of the enzyme in apoptotic cells. It appears that other regions of the promoter with regulatory activity in hepatic and myocardial cells will have to be identified before the full repertoire of regulatory control of transglutaminase gene expression can be adequately addressed.

\section{Materials and Methods}

Materials HeLa cells were purchased from the American Type Culture Collection (ATCC., Rockville, MD). pBluescript SK II was purchased from Stratagene (San Diego $\mathrm{CA}$ ). $\mathrm{pSV}_{2}$-Hygro was a gift from $\mathrm{Dr}$ Salman Hyder (Univ. of Texas-Houston, Houston, TX) and pLacF (Mercer, 1991 \#150) was a gift of Dr Richard Behringer (MD Anderson Cancer Center, Houston, TX). 9-cis RA, TTNPB, AM-80, LG1069, were obtained from the Allergan-Ligand Joint Venture in Retinoid Research (San Diego and Irvine, CA). Stock solutions of retinoids were prepared in ethanol and stored in the dark at $-20^{\circ} \mathrm{C}$.

Cell culture HeLa cells were grown in Dulbecco's Modified Eagle's Medium (DMEM) supplemented with 10\% fetal calf serum (Irvine Scientific, Santa Ana, CA) and $1 \%$ penicillin/streptomycin at $37^{\circ} \mathrm{C}$ in the presence of $5 \% \mathrm{CO}_{2}$.

Enzyme assays $\beta$-Galactosidase activity was assayed in transfected cells either by using the Promega $\beta$-Galactosidase Enzyme Assay System (Promega, Madison, WI) or by using Galacto-Light Chemiluminescent Reporter Assay (Tropix, Inc., Bedford, MA). For enzymatic assays, cell extracts $(100 \mu \mathrm{l})$ were incubated with $2 \times$ buffer (120 mM Na $2 \mathrm{HPO}_{4}, 80 \mathrm{mM} \mathrm{NaH} \mathrm{PO}_{4}, 2 \mathrm{mM} \mathrm{MgCl}, 100 \mathrm{mM} \beta$ mercaptoethanol, $1.33 \mathrm{mg} / \mathrm{ml} \mathrm{ONPG)} \mathrm{for} 2 \mathrm{~h}$. The reaction was terminated by the addition of $300 \mu$ of $1 \mathrm{M}$ sodium carbonate and the absorbance of the reaction was measured at $420 \mathrm{~nm}$. In the chemiluminescence assay, cells were lysed in $100 \mathrm{mM}$ potassium phosphate $\mathrm{pH} 7.8,0.2 \%$ Triton $\mathrm{X}-100$ and $1 \mathrm{mM}$ dithiothreitol. Assays were carried out according to manufacturer's protocol and measured in a Monolight 2010 luminometer (Analytical Luminescence Laboratory, San Diego, CA), values above non-specific background and standard deviation is presented.

To assay tissue transglutaminase activity, cell lysates were prepared by scraping the cells in $100 \mu$ l phosphate buffered normal saline. Cells were homogenized by sonication with Sonicator Model 
W-225R at $50 \%$ on ice for $20 \mathrm{~s}$. Transglutaminase activity was assayed as described previously (Moore et al, 1984). Briefly, cell lysates were prepared and incubated in the presence of $\left[{ }^{3} \mathrm{H}\right]$ putrescine, $\mathrm{N}, \mathrm{N}$ dimethylcasein and either $5 \mathrm{mM} \mathrm{Ca}^{2+}$ or EGTA. The $\mathrm{Ca}^{2+}$-dependent covalent conjugation of putrescine to $\mathrm{N}, \mathrm{N}$-dimethylcasein was determined and expressed as enzyme activity (pmol/min $/ \mathrm{mg}$ protein). The protein content of lysates was determined using a Bio-Rad Protein Assay kit (Bio-Rad Laboratories, Hercules, CA).

Transfection protocols For the stable transfection of HeLa cells, cells were transfected with Lipofectin Reagent (GibcoBRL, Gaithersburg,

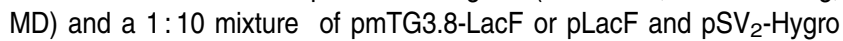
using standard methods. The selection for hygromycin resistant clones was carried out in the presence of $150 \mu \mathrm{g} / \mathrm{ml}$ Hygromycin B (Calbiochem, La Jolla, CA) in DMEM with $10 \%$ fetal calf serum. Colonies derived from a single cell were cloned and propagated individually. Integration of the plasmid DNA was determined by Southern hybridization and PCR analysis. Clones C-4 from transfections with the control plasmid (pLacF) and 4-2 from transfection with pmTG3.8-LacF were selected for characterization.

Genomic library screening Four million recombinant phage from a $\mathrm{NIH} 3 \mathrm{T3}$ mouse library in a $\lambda$-fix II vector (Stratagene, La Jolla, CA)) grown in $E$. coli LE-392 were screened with a ${ }^{32} \mathrm{P}$-labeled mouse tissue transglutaminase cDNA insert from clone pmTG7-4 (Gentile et al, 1991). Positive clones were subjected to a secondary screening with ${ }^{32} \mathrm{P}$-end-labeled oligonucleotide probes (mTG14a, mTG18a, mTG22s, Table 1). Only one of these clones, $\lambda m$ mTG-GC3, reacted positively with both oligos mTG14a and mTG18a as well as the cDNA probe. The DNA insert from $\lambda \mathrm{mTG}-\mathrm{GC} 3$ was isolated and characterized by a combination of restriction enzyme mapping and Southern blot analysis. A $5.8 \mathrm{kB}$ Sacl fragment, which contained tissue transglutaminase exons I and II was subcloned into pBluescript SK II (pmTG5.8) for further analysis.

S1-nuclease protection assay S1-Nuclease analysis was performed according to the procedure described in Ausubel et al, 1987). A 993nucleotide $\mathrm{Ncol}$ fragment $(-926$ to +67$)$ of pmTG5.8 was gel purified and 5 -labeled with T4 polynucleotide kinase and $\left[\gamma^{32}\right.$ P]ATP. This labeled fragment was hybridized either to $12 \mu \mathrm{g}$ of total RNA isolated from ATRA - treated and control mouse peritoneal macrophages or to $2 \mu \mathrm{g}$ of poly $(\mathrm{A})^{+}$RNA from mouse heart, liver and kidney and then it was subjected to digestion with S-1 nuclease. Protected fragments were analyzed on a denaturing $8 \%$ polyacrylamide/urea gel with a sequencing ladder of M13mp18 plasmid DNA (United States Biochemical Corp., Cleveland, $\mathrm{OH}$ ) as a size standard. Radiolabeled bands were detected by autoradiography.

RNase protection assay ${ }^{32}$ PUTP-labeled antisense riboprobes for human $\operatorname{RAR} \alpha, \operatorname{RAR} \beta, \operatorname{RAR} \gamma, \operatorname{RXR} \alpha, \operatorname{RXR} \beta$ and $\gamma$-actin were generated from 100-150 bp fragments of their respective cDNAs that had been cloned into a pGEM-4Z vector (Promega Inc., Madison, WI). Total RNA $(10 \mu \mathrm{g})$, prepared by a one step method (Tri-Reagent, Molecular Research Center, Inc., Cincinnati, $\mathrm{OH}$ ) was hybridized to the radiolabeled riboprobes and digested with RNases $A$ and $T_{1}$ under conditions described in detail previously (Nagy et al, 1995). Autoradiograms were scanned, digitalized and the relative intensity of the protected bands were determined by using PDQUEST ${ }^{\mathrm{TM}}$ Quantity One Scanning and Analysis Program (PDI, Inc. Huntington Station, NY) on a Sun Workstation. The measured band intensities were normalized for the number of uridine residues in each probe and for the intensity of the bands of the internal control, $\gamma$-actin.
PCR protocols: PCR analysis of genomic DNA To detect $\beta$ galactosidase DNA in transfected HeLa cells or from DNA of mouse tail biopsies, genomic DNA was prepared from transfected cell lines or mouse tail biopsies using standard phenol/chloroform - based methodology (Ausubel et al, 1987). $1 \mu \mathrm{g}$ of DNA was used in PCR reactions with $0.5 \mathrm{mM}$ primers GAL3s and GAL4a. The reaction mixture included $5 \mathrm{U}$ AmpliTaq DNA polymerase (Perking Elmer, Roche Molecular Systems, Inc, Branchburg, NJ), dNTP's $(200 \mu \mathrm{M})$, $10 \times$ reaction buffer and $1.5 \mathrm{mM} \mathrm{MgCl}_{2}$. Reactions were carried out in a programmable thermal cycler as follows: initial melting $94^{\circ} \mathrm{C}$ for $4 \mathrm{~min}$, then cycles of melting at $94^{\circ} \mathrm{C}$ for $1 \mathrm{~min}$, annealing $55^{\circ} \mathrm{C}$ for $2 \mathrm{~min}$, elongation at $72^{\circ} \mathrm{C}$ for $2 \mathrm{~min}$, final extension $72^{\circ} \mathrm{C}$ for $7 \mathrm{~min}$.

PCR protocols: Anchored PCR We used anchored PCR to identify the transcription start site of the mouse tissue transglutaminase gene (Frohman, 1990). Adult ICR strain male mice (Charles River Labs, Wilmington, MA) were sacrificed and peritoneal macrophages isolated by lavage (Moore et al, 1984). Total RNA was prepared by the guanidine thiocyanate method (Chirgwin et al, 1979) from mouse macrophages treated for $16 \mathrm{~h}$ with $1 \mu \mathrm{M}$ ATRA in $10 \%$ delipidized mouse serum (Moore et al, 1984). To make a cDNA transcript $20 \mu \mathrm{g}$ of denatured mouse macrophage RNA was incubated with 10 pmoles of the mouse tissue transglutaminase antisense oligonucleotide mTG5t3a, 10 units of AMV reverse transcriptase, $1 \times$ PCR buffer (Perkin Elmer Cetus, Emeryville, CA), $5 \mathrm{mM} \mathrm{MgCl}_{2}, 10$ units of RNasin (Promega, Madison, $\mathrm{WI}$ ). Reverse transcription was for $1 \mathrm{~h}$ at $42^{\circ} \mathrm{C}$, followed by $30 \mathrm{~min}$ at $52^{\circ} \mathrm{C}$ before excess primer was removed using a Centricon 100 spin filter (Amicon Corp, Beverly, MA). Residual RNA was degraded by digestion with RNase $\mathrm{A}(50 \mu \mathrm{g} / \mathrm{ml})$ at $37^{\circ} \mathrm{C}$ for $30 \mathrm{~min}$. A homopolymer tail was added to the transglutaminase cDNA by addition of $1 \mathrm{mM}$ dATP, 10 units of terminal deoxynucleotidyl-transferase (BRL, Gaithersburg, MD) and incubation for $10 \mathrm{~min}$ at $37^{\circ} \mathrm{C}$ and then $10 \mathrm{~min}$ at $65^{\circ} \mathrm{C}$. Excess dATP was removed using a Centricon 100 spin column and 1/10 of the product was used in the PCR reaction. The tailed cDNAs were amplified using 10 pmoles of Hybrid $\mathrm{dT}_{17}$-adaptor primer, 25 pmoles of adaptor primer and 25 pmoles of a mouse tissue transglutaminase sense oligonucleotide mTG14a in a reaction mixture containing $15 \mathrm{mM}$ of dNTPs (each), $2.5 \mathrm{mM} \mathrm{MgCl}_{2}, 10 \mu \mathrm{l}$ of DMSO and $1 \times \mathrm{PCR}$ buffer in a $100 \mu \mathrm{l}$ volume overlaid with $100 \mu \mathrm{l}$ of mineral oil. This mixture was denatured for $5 \mathrm{~min}$ at $95^{\circ} \mathrm{C}$, and cooled to $72^{\circ} \mathrm{C}$ before the addition of 2.5 units of Ampli Taq DNA polymerase (Perkin Elmer Cetus, Emeryville, $\mathrm{CA})$. The PCR conditions were as follows: The primers were annealed at $55^{\circ} \mathrm{C}$ for $5 \mathrm{~min}$ and extended at $72^{\circ} \mathrm{C}$ for $40 \mathrm{~min}$, followed by 40 cycles of $95^{\circ} \mathrm{C}$ for $40 \mathrm{~s} / 55^{\circ} \mathrm{C}$ for $1 \mathrm{~min} / \mathrm{and} 72^{\circ} \mathrm{C}$ for $3 \mathrm{~min}$. The reaction was finished by an extension step for $15 \mathrm{~min}$ at $72^{\circ} \mathrm{C}$. The PCR products were cloned into the Xmalll and EcoRI sites in the vector pBluescript SK II (Stratagene, La Jolla, CA). One thousand recombinant colonies were plated and subclones containing transglutaminase cDNA inserts were detected by replica colony hybridization with either a ${ }^{32} \mathrm{P}$-labeled cDNA insert from clone pmTG7-4 or the ${ }^{32} \mathrm{P}$-end labeled transglutaminase oligonucleotide mTG19a.

PCR protocols: $R T-P C R$ Stably transfected HeLa cell lines C-4 and 4-2 were cultured in DMEM supplemented with $10 \%$ fetal calf serum and $150 \mu \mathrm{g} / \mathrm{ml}$ Hygromycin B in 6-well tissue culture dishes. For retinoid treatment, the medium was changed for DMEM supplemented with $2 \%$ fetal calf serum and ATRA $(1 \mu \mathrm{M})$ or a matched solvent $(<0.1 \%$ ethanol) control. The cells were cultured for an additional $72 \mathrm{~h}$. Total RNA was prepared by using the phase lock gel system ( 5 prime-3 prime, Inc., Boulder, $\mathrm{CO}$ ) following manufacturer's suggested protocol. Reverse transcription was carried out using $1 \mu \mathrm{g}$ of total RNA in $60 \mu \mathrm{l}$ reaction mixtue containing $50 \mathrm{mM}$ Tris- $\mathrm{HCl}(\mathrm{pH} 8.3), 75 \mathrm{mM}$ 
$\mathrm{KCl}, 3 \mathrm{mM} \mathrm{MgCl} 2,10 \mathrm{mM}$ DTT, $0.5 \mathrm{mM}$ of each dNTP, $2 \mathrm{U}$ of MoMuLV reverse transcriptase $10 \mu \mathrm{g} / \mathrm{ml}$ oligo- $\mathrm{dT}_{15}$. After an incubation at $42^{\circ} \mathrm{C}$ the reaction was stopped by incubation at $99^{\circ} \mathrm{C}$ for $5 \mathrm{~min}$. The $\mathrm{PCR}$ reaction was carried out using $60 \mu \mathrm{l}$ from the reverse transcription reaction in $10 \mathrm{mM}$ Tris- $\mathrm{HCl}(\mathrm{pH} \mathrm{8.3)}, 50 \mathrm{mM} \mathrm{KCl}, 1.5 \mathrm{mM} \mathrm{MgCl}$, $200 \mu \mathrm{M}$ of each dNTP, $1 \mathrm{U}$ of AmpliTaq DNA polymerase (PerkinElmer, Cetus Corp., Emeryville, CA). Primers GAL3s and GAL4a were added to a final concentration of $0.5 \mathrm{mM}$. The reaction mixture was overlaid with a drop of mineral oil. The thermal cycler was programmed for $94^{\circ} \mathrm{C}$ for $1 \mathrm{~min}, 60^{\circ} \mathrm{C}$ for $2 \mathrm{~min}, 72^{\circ} \mathrm{C}$ for $3 \mathrm{~min}$ and $72^{\circ} \mathrm{C}$ for $7 \mathrm{~min}$.

Southern blot analysis Genomic DNA from the indicated HeLa cell lines or from DNA of mouse tail biopsies and increasing amounts of pLacF plasmid was transferred to Zeta Probe Blotting Membranes (Bio-Rad Laboratories, Hercules, CA) using a Bio-Rad Slot-blot apparatus and the manufacturer's suggested method. Membranes were probed with ${ }^{32} \mathrm{P}$-labeled $1 \mathrm{~kb}$ fragment of pLacF in hybridization solution (7\% SDS, $0.5 \mathrm{M} \mathrm{Na}_{2} \mathrm{HPO}_{4} \mathrm{pH} 7.2$ and $1 \mathrm{mM}$ EDTA) at $65^{\circ} \mathrm{C}$ for $16 \mathrm{~h}$. After hybridization membranes were washed at $65^{\circ} \mathrm{C}$ in $5 \%$ SDS, $40 \mathrm{mM} \mathrm{Na}_{2} \mathrm{HPO}_{4} \mathrm{pH} 7.2$ and $1 \mathrm{mM}$ EDTA for $30 \mathrm{~min}$ and then in $1 \% \mathrm{SDS}, 40 \mathrm{mM} \mathrm{Na} 2 \mathrm{HPO}_{4} \mathrm{pH} 7.2$ and $1 \mathrm{mM}$ EDTA for an additional $30 \mathrm{~min}$. The membranes were imaged and radioactivity quantitated by using a Betascope603 Blot Analyzer (Betagene Corp., Waltham, MA).

Plasmid constructs: pmTG3.8-LacF A $0.9 \mathrm{~kb}$ Ncol fragment from a subcloned $2.1 \mathrm{~kb}$ (Sacll) piece of the genomic clone (2mTG-GC3) was cloned into the $\mathrm{Ncol}$ site of pLacF (Mercer, 1991 \#150) to generate pmTG0.9 LacF. An Eagl/Sall fragment from pBC2.1 was cloned into Eagl/Sall digested pmTG0.9-LacF to give pmTG1.8-LacF. Plasmid pmTG4.3 was generated by cloning a $4.3 \mathrm{~kb}$ fragment $(-6 \mathrm{~kb}$ to $-2 \mathrm{~kb}$ ) of the mouse tissue transglutaminase genomic DNA I-phage clone (ImTG-GC3) into pBC using Pstl sites and a $2 \mathrm{~kb} K p n l / P s t$ fragment of this plasmid was subsequently cloned into Kpnl/Pstl digested pBC2.1 to generate pBC 4.5. A $3.7 \mathrm{~kb} K p n l-E a g l$ fragment of pBC4.5 was cloned into Kpnl/Eagl digested pmTG 0.9acF to generate pmTG3.8 lac. The resulting chimeric reporter gene (pmTG3.8-LacF) contains the $3.8 \mathrm{~kb}$ fragment of the mouse tissue transglutaminase promoter fused to the $E$. coli $\beta$-galactosidase structural gene.

Transgenic animals Transgenic animals were generated by standard microinjection methods by DNX, Corp. Princeton, NJ. Founder animals were identified from tail biopsies by PCR and Southern blotting as described above in the case of the stably transfected HeLa cells.

The selected founders (TG-LN \#26 and TG-LN \#27) were inbred into C57/B6 background to at least F3. Embryos were obtained by Cesarian sections after the indicated period p.c.

Tail biopsies and preparation of DNA 3-4 week old mice were ether anaesthetized and $1-1.5 \mathrm{~cm}$ tail biopsies were cut. Biopsies were digested overnight at $55^{\circ} \mathrm{C}$ in Tail buffer $(50 \mathrm{mM}$ ris-Hcl $\mathrm{pH} 8.0$, $100 \mathrm{mM}$ EDTA, $100 \mathrm{mM} \mathrm{NaCl}, 10 \%$ SDS $0.5 \mathrm{mg} / \mathrm{ml}$ Proteinase $\mathrm{K}$. Genomic DNA was prepared by standard phenol-chloroform based methodology (Ausubel et al, 1987).

$\beta$-Galactosidase activity $\beta$-galactosidase activity was visualized by $\mathbf{x}$ gal staining. Embryos were fixed for $10 \mathrm{~min}$ in a fixative containing $0.1 \mathrm{M}$ Phosphate buffer ( $\mathrm{pH} 7.3$ ), 0.2\% glutaraldehyde, $5 \mathrm{mM}$ EGTA and $2 \mathrm{mM} \mathrm{MgCl}$. Embryos were rinsed three times in a Rinsing solution (0.1 M Phosphate buffer ( $\mathrm{pH} 7.3$ ), $2 \mathrm{mM} \mathrm{MgCl}_{2}, 0.01 \%$ sodium deoxycholate and $0.02 \%$ Nonidet P-40) and stained for the indicated period of time in Staining solution (Rinsing solution plus $5 \mathrm{mM}$ potassium ferricyanide, $5 \mathrm{mM}$ postassium ferrocyanide and $1 \mathrm{mg} / \mathrm{ml} \mathrm{X}$ gal (5-bromo-4-chloreo-3-indolyl- $\beta$-D galactopyramoside)). After staining lacZ expression was observed and embryos were postfixed in $4 \%$ formaldehyde, dehydrated and embedded into glycolmethacrylate. Ten $\mu \mathrm{m}$ thick sections were counter stained with hematoxylin.

Immunohistochemical detection of tissue transglutaminase For immunoperoxidase or immuno-alkaline phosphates labeling embryos were collected at day 13.5 p.c., fixed in $4 \%$ formaldehyde overnight, dehydrated and embedded into paraffin. Five $\mu \mathrm{m}$ thick sections were dewaxed and heat-treated in a microwave oven, endogenous peroxidase was inhibited by $0.1 \mathrm{M}$ periodic acid for $5 \mathrm{~min}$. Non-specific binding sites were blocked by pretreating the slides for $20 \mathrm{~min}$ in $2 \%$ non-fat dry milk in TBS. Primary antibody was an affinity purified goat anti guinea pig liver transglutaminase at $5 \mu \mathrm{g} / \mathrm{ml}$ or preimmune serum at $1: 2000$ dilution. Incubation with the primary antibody was for $2 \mathrm{~h}$ at room temperature in TBS pH 7.2 containing $0.5 \mathrm{M} \mathrm{NaCl}$ and $2 \%$ milk. After washing for $3 \times 5 \mathrm{~min}$ in $0.5 \mathrm{M} \mathrm{NaCl}$-TBS sections were treated with a biotinylated horse anti-goat IgG (Vector Labs, Burlingame, CA) at 1:150 dilution in TBS pH 7.2 containing $0.5 \mathrm{M} \mathrm{NaCl}$ and $2 \%$ milk for $1 \mathrm{~h}$. Sections were washed as above and exposed to avidin-HRPO or avidin-alkaline phosphatase (both from Vector Labs, Burlingame, CA) at 1:1000 and 1:200 dilution for $30 \mathrm{~min}$. Following washes the immunoreaction was developed using respectively DAB (Sigma) or NBT-phosphate mixture (Boehringer-Mannheim).

Immunofluorescent labeling was similar except that fresh formaldehyde-fixed cryostat sections were used, microwave treatment and periodic acid blocking were omitted, and the third incubation step was with a 1:200 dilution of avidin-Texas red(Vector) rather than an enzyme-avidin conjugate.

\section{Acknowledgements}

This work was supported in part by research grant DK27078 from the National Institutes of Health to P.J.A.D. We gratefully acknowledge $\mathrm{Dr}$ Andrea Karoly's help with the RT-PCRs and the technical assistance of Ms. Mary Sobieski in the conduct of experiments reported here. We thank Dr Shan Lu for figure $1 \mathrm{~A}$ and Ms. Joan Jennings for her secretarial assistance in the preparation of the manuscript.

\section{References}

Aeschlimann D and Paulsson M (1991) Cross-linking of laminin-nidogen complexes by tissue transglutaminase. A novel mechanism for basement membrane stabilization. J. Biol. Chem. 266: 15308-15317

Aeschlimann D and Paulsson M (1994) Transglutaminases: protein cross-linking enzymes in tissues and body fluids. Thromb. Haemost. 71: 402-415

Aeschlimann D, Wetterwald A, Fleisch Hand Paulsson M (1993) Expression of tissue transglutaminase in skeletal tissue correlates with events of terminal differentiation of chondrocytes. J. Cell. Biol. 120: 1461-1470

Astrom A, Pettersson U, Chambon P and Voorhees JJ (1994) Retinoic acid induction of human cellular retinoic acid-binding protien-II gene transcription is mediated by retinoic acid receptor-retinoid $X$ receptor heterodimers bound to one far upstream retinoic acid-responsive element with 5-base pair spacing. J. Biol. Chem. 269: 22334-22339

Ausubel FM, Brent R, Kingston RE, Moore DD, Seidman JG, Smith JA and Struhl K (1987) Current protocols in molecular biology (New York, NY: John Wiley and Sons)

Barsigian C, Stern AM and Martinez J (1991) Tissue (type II) transglutaminase covalently incorporates itself, fibrinogen, or fibronectin into high molecular weight complexes on the extracellular surface of isolated hepatocytes. Use of 2[(2-oxopropyl)thio] imidazolium derivatives as cellular transglutaminase inactivators. J. Biol. Chem. 266: 22501-22509 
Boehm MF, McClurg M, Pathirana C, Mangelsdorf D, White SK, Hebert J, Winn D, Goldman Mand Heyman RA (1994) Synthesis of a high specific activity [ $\left.{ }^{3} \mathrm{H}\right]$-9-cis retinoic acid and its application for identifying retinoids with unusual binding properties. Journal of Medicinal Chemistry 37: 408-414

Bowness JM, Tarr AH and Wong T (1988) Increased transglutaminase activity during skin wound healing in rats. Biochim. Biophys. Acta 967: 234-240

Cash DE, Bock CB, Schughart K, Linney E and Underhill MT (1997) Retinoic acid receptor $\alpha$ function in vertebrate limb skeletogenesis: a modulator of chondrogenesis. J. Cell. Biol. 136: 445-457

Chen JD and Evans RM (1995) A Transcriptional Co-Repressor That Interacts With Nuclear Hormone Receptors. Nature 377: 454-457

Chiocca EA, Davies PJ and Stein JP (1988) The molecular basis of retinoic acid action. Transcriptional regulation of tissue transglutaminase gene expression in macrophages. J. Biol. Chem. 263: 11584-11589

Chirgwin JM, Przybyla AE, MacDonald RJ and Rutter WJ (1979) Isolation of biologically active ribonucleic acid from sources enriched in ribonuclease. Biochemistry 18: 5294-5299

Davies PJA, Chiocca EA, Basilion JP, Poddar S and Stein J (1989) Transglutaminases and their regulation: implications for polyamine metabolism. In International symposium on polyamines in biochemical and clinical research, V Zappia and AE Pegg, eds. (Sorrento (Naples), Italy: Plenum Press), pp. $165-173$

Davies PJA, Murtaugh MP, Moore WT, Johnson GS and Lucas D (1985) Retinoic acid-induced expression of tissue transglutaminase in human promyelocytic leukemia (HL-60) cells. J. Biol. Chem. 260: 5166-5174

Dolle P, Ruberte E, Kastner P, Petkovich M, Stoner CM, Gudas LJ and Chambon P (1989) Differential expression of genes encoding alpha, beta and gamma retinoic acid receptors and CRABP in the developing limbs of the mouse. Nature 342: $702-705$

Fesus L, Davies PJA and Piacentini M (1991) Apoptosis: molecular mechanisms in programmed cell death. European J. Cell. Biol. 56: 170-177

Fesus L, Tarcsa E, Kedei N, Autuori F and Piacentini M (1991) Degradation of cells dying by apoptosis leads to accumulation of epsilon(gamma-glutamyl)lysine isodipeptide in culture fluid and blood. FEBS Lett. 284: 109-112

Fesus L, Thomazy V, Autuori F, Ceru MP, Tarcsa E and Piacentini M (1989) Apoptotic hepatocytes become insoluble in detergents and chaotropic agents as a result of transglutaminase action. FEBS Lett. 245: 150-154

Fesus L, Thomazy V and Falus A (1987) Induction and activation of tissue transglutaminase during programmed cell death. FEBS Lett. 224: 104-108

Folk JE (1980) Transglutaminases. Annual. Rev. Biochem. 49: 517-531

Frohman MA (1990) RACE: Rapid Amplification of cDNA Ends. In PCR Protocols: A guide to methods and applications: Academic Press), pp. 298-338

Fukasawa H, lijima T, Kagechika H, Hashimoto $Y$ and Shudo K (1993) Expression of the ligand-binding domain-containing region of retinoic acid receptors alpha, beta and gamma in Escherichia coli and evaluation of ligand-binding selectivity. Biol. Pharm. Bull. 16: 343-348

Gentile V, Saydak M, Chiocca EA, Akande O, Birckbichler PJ, Lee KN, Stein JP and Davies PJ (1991) Isolation and characterization of cDNA clones to mouse macrophage and human endothelial cell tissue transglutaminases. J. Biol. Chem. 266: $478-483$

Goldman R (1987) Modulation of transglutaminase activity in mononuclear phagocytes and macrophage-like tumor cell lines by differentiation agents. Exp. Cell. Res. 168: 31-43

Greenberg CS, Birckbichler PJ and Rice RH (1991) Transglutaminases: multifunctional cross-linking enzymes that stabilize tissues. Faseb. J. 5: 3071-3077

Helms JA, Kim CH, Eichele G and Thaller C (1996) Retinoc acid signaling is required during early chick limb development. Development 122: 1385-1394

Horlein AJ, Naar AM, Heinzel T, Torchia J, Gloss B, Kurokawa R, Ryan A, Kamel Y, Soderstrom M, Glass CK and Rosenfeld MG (1995) Ligand-Independent Repression By the Thyroid Hormone Receptor Mediated By a Nuclear CoRepressor. Nature 377: 397-404

Jiang $\mathrm{H}$ and Kochhar DM (1992) Induction of tissue transglutaminase and apoptosis by retinoic acid in the limb bud. Teratology $46: 333-340$

Johnson JD and Davies PJ (1986) Pertussis toxin inhibits retinoic acid-induced expression of tissue transglutaminase in macrophages. J. Biol. Chem. 261: $14982-14986$

Kastner P, Mark M and Chambon P (1995) Nonsteroid nuclear receptors - What are genetic studies telling us about their role in real life. Cell 83: 859-869
Kochhar DM, Jiang H, Harnish DC and Soprano DR (1993) Evidence that retinoic acid-induced apoptosis in the mouse limb bud core mesenchymal cells is genemediated. Prog. Clin. Biol. Res. 383B: 815-825

Kurokawa R, DiRenzo J, Boehm M, Sugarman J, Gloss B, Rosenfeld MG, Heyman RA and Glass CK (1994) Regulation of retinoid signaling by receptor polarity and allosteric control of ligand binding. Nature 371: 528-531

Langston AW and Gudas LJ (1992) Identification of a retinoic acid responsive enhancer $3^{\prime}$ of the murine homeobox gene hox 1.6. Mech. Dev. 38: 217-227

Lichti $U$ and Yuspa SH (1988) Modulation of tissue and epidermal transglutaminases in mouse epidermal cells after treatment with 12-0-tetradecanoylphorbol-13acetate and/or retinoic acid in vivo and in culture. Cancer Res. 48: 74-81

Maddox AM and Haddox MK (1985) Transglutaminase activity increases in HL60 cells induced to differentiate with retinoic acid and TPA but not with DMSO. Exp. Cell. Biol. 53(5): 294-300

Mangelsdorf DJ (1994) Vitamin A receptors. Nutr. Rev. 52: S32-44

Mangelsdorf DJ, Umesono K and Evans RM (1994) The retinoid receptors. In The retinoids, MB Sporn, AB Roberts and DS Goodman eds (New York: Raven Press), pp. 319-350

Mendelsohn C, Ruberte E, LeMeur M, Morriss-Kay G and Chambon P (1991) Developmental analysis of the retinoic acid-inducible RAR-beta 2 promoter in transgenic animals. Development 113: 723-734

Moore WT Jr, Murtaugh MP and Davies PJ (1984) Retinoic acid-induced expression of tissue transglutaminase in mouse peritoneal macrophages. J. Biol. Chem. 259: $12794-12802$

Nagy L, Saydak M, Shipley N, Lu S, Basilion JP, Yan ZH, Syka P, Chandraratna R, Heyman R and Davies PJA (1996) Identification and characterization of a versatile retinoid response element (RARE/RXRE) in the promoter of the mouse tissue transglutaminase gene. J. Biol. Chem. 271: 4355-4365

Nagy L, Thomazy VA and Davies PJA (1994) Tissue transglutaminse: an effector in physiologic cell death. Cancer Bulletin 46: 136-140

Nagy L, Thomazy VA, Heyman RA, Chandraratna RAS and Davies PJA (1996) Retinoid-regulated expression of BCL-2 and tissue transglutaminase during differentiation and apoptosis of human myeloid leukemia (HL-60) cells. Leukemia Research 19: 499-505

Nagy L, Thomazy VA, Shipley GLLF, Lamph W, Heyman RA, Chandraratna RAC and Davies PJA (1995) Activation of Retinoid X Receptors (RXR) induces apoptosis in HL-60 cell lines. Mol. Cell. Biol. 15: 3540-3551

Nemes Z, Friis RR, Aeschliman D, Sauer S, Paulson M and Fesus L (1996) Expression and activation of tissue transglutaminase in apoptotic cells of involuting rodent mammary tissue. Eur. J. Cell. Biol. 70: 125-1333

Oettinger HF and Pacifici M (1990) Type X collagen expression is transiently upregulated by retinoic acid treatmentin chick chondrocyte cultures. Exp. Cell. Res. 191: 292-298

Pacifici M, Golden EB, Iwamoto M and Adams SL (1991) Retinoic acid treatment induces type $X$ collagene gene expression in cultured chick chondrocytes. Exp. Cell. Res. 195: 38-46

Piacentini M, Annicchiarico-Petruzzelli M, Oliverio S, Piredda L, Biedler JL and Melino E (1992a) Phenotype-specific 'tissue' transglutaminase regulation in human neuroblastoma cells in response to retinoic acid: correlation with cell death by apoptosis. Int. J. Cancer 52: 271-278

Piacentini M, Ceru MP, Dini L, Di Rao M, Pirreda L, Thomazy V, Davies PJA and Fesus $L(1992 b)$ In vivo and in vitro induction of tissue transglutaminase in rat hepatocytes by retinoic acid. Biochim. Biophys. Acta 171-179

Piacentini M and Melino G (1994) Role of tissue transglutaminase in neuroblastoma cells undergoing apoptosis. Prog. Clin. Biol. Res. 385: 123-129

Szondy Z, Molnar P, Nemes Z, Boyiadzis M, Kedei N, Toth R and Fesus L (1997) Differential expression of tissue transglutaminase during in vivo apoptosis of thymocytes induced via distinct signalling pathways. FEBS Lett. 404: 307-313

Thomazy $V$ and Fesus $L$ (1989) Differential expression of tissue transglutaminase in human cells. An immunohistochemical study. Cell. Tissue Res. 255: 215-224

Verma AK, Shoemaker A, Simsiman R, Denning M and Zachman RD (1992) Expression of retinoic acid nuclear receptors and tissue transglutaminase is altered in various tissues of rats fed a vitamin A-deficient diet. J. Nutr. 122: 2144-2152

Ywamoto M, Shapiro IM, Yagami K, Baskey AL, Leboy PS, Adams SL and Pacifici M (1993) Retinoic acid induces rapid mineralization and expression of mineralization-related genes in chondrocytes. Exp. Cell. Res. 207: 413-420

Ywamoto M, Yagami K, Shapiro IM, Leboy PS, Adams SL and Pacifici M (1994) Retinoic acid is a major regulator of chondrocyte maturation and matrix mineralization. Microsc. Res. Tech. 28: 483-491 